Prepared in cooperation with the City of Cedar Rapids Utilities Water Division

\title{
Selected Water-Quality Data from the Cedar River and Cedar Rapids Well Fields, Cedar Rapids, lowa, 2008-17
}

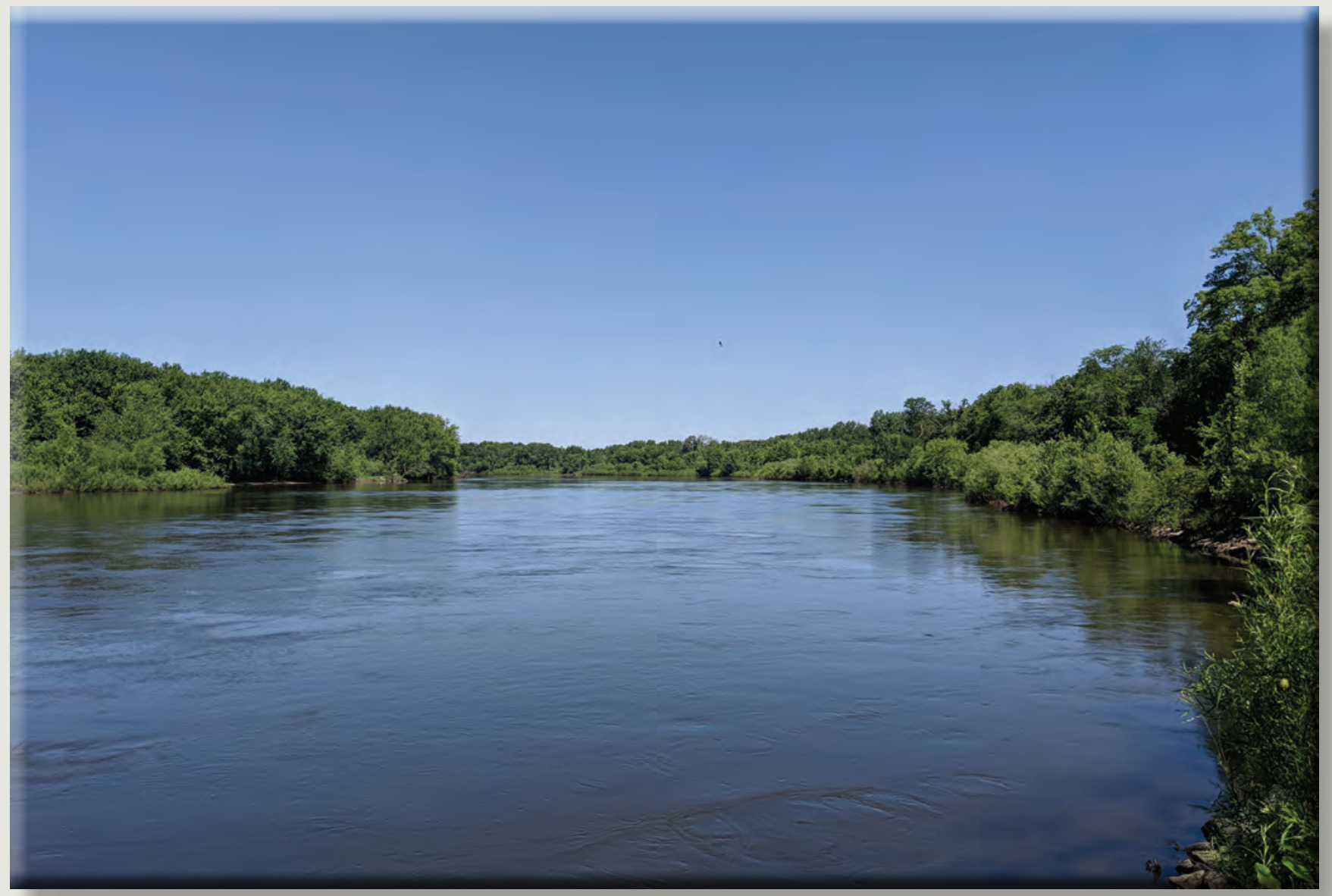

Data Series 1110 
Cover. Photograph showing river as looking upstream from CRM-4A in Seminole well field, Cedar Rapids, lowa, during high flows, June 4, 2018. Photograph taken by Shannon Meppelink, U.S. Geological Survey.

Back cover. Photograph showing Edgewood Ranney 3 pumps in the wellhouse, Cedar Rapids, lowa, 2003 (upper left). Photograph showing a vertical well in Seminole well field, Cedar Rapids, lowa, August 24, 2015 (right). Photograph showing Seminole Ranney 4 in Seminole well field, Cedar Rapids, lowa, October 8, 2003 (lower left). Photographs by U.S. Geological Survey. 


\section{Selected Water-Quality Data from the Cedar River and Cedar Rapids Well Fields, Cedar Rapids, lowa, 2008-17}

By Shannon M. Meppelink, Erin A. Stelzer, Emilia L. Bristow, and Gregory R. Littin

Prepared in cooperation with the City of Cedar Rapids Utilities Water Division

Data Series 1110 


\title{
U.S. Department of the Interior \\ DAVID BERNHARDT, Acting Secretary
}

\author{
U.S. Geological Survey \\ James F. Reilly II, Director
}

U.S. Geological Survey, Reston, Virginia: 2019

For more information on the USGS - the Federal source for science about the Earth, its natural and living resources, natural hazards, and the environment-visit https://www.usgs.gov or call 1-888-ASK-USGS.

For an overview of USGS information products, including maps, imagery, and publications,

visit https://store.usgs.gov.

Any use of trade, firm, or product names is for descriptive purposes only and does not imply endorsement by the U.S. Government.

Although this information product, for the most part, is in the public domain, it also may contain copyrighted materials as noted in the text. Permission to reproduce copyrighted items must be secured from the copyright owner.

Suggested citation:

Meppelink, S.M., Stelzer, E.A., Bristow, E.L., and Littin, G.R., 2019, Selected water-quality data from the Cedar River and Cedar Rapids well fields, Cedar Rapids, lowa, 2008-17: U.S. Geological Survey Data Series 1110, 49 p.,

https://doi.org/10.3133/ds1110.

ISSN 2327-638X (online) 


\section{Acknowledgments}

The authors would like to acknowledge the City of Cedar Rapids Utilities Water Division that provides support for this long-term (more than 20 years) project.

Water-quality samples were collected by personnel from the U.S. Geological Survey. Data tables were reviewed by Shelby Sterner of the U.S. Geological Survey. This report was reviewed by Kristin Romanok and Jessica D. Garrett of the U.S. Geological Survey. 



\section{Contents}

Acknowledgments ……...................................................................................................................

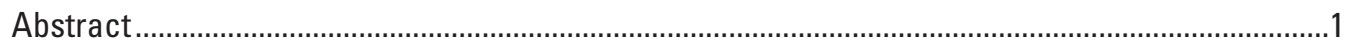

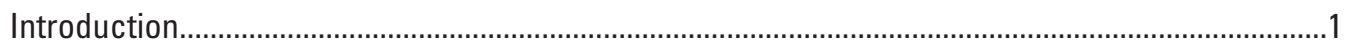

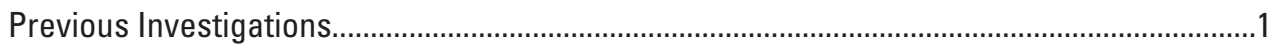

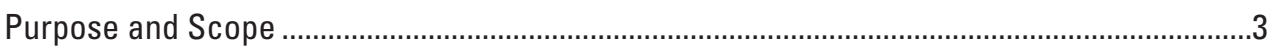

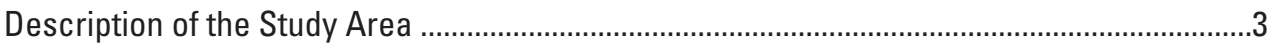

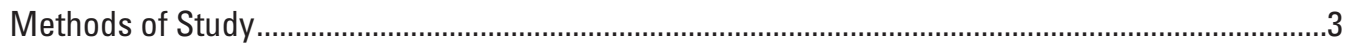

Well Construction and Nomenclature .....................................................................................

Water-Quality Sampling .........................................................................................................

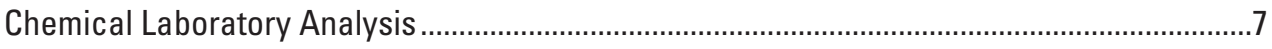

Sample Concentration for Viral Pathogens .............................................................................

DNA/RNA Extraction and qPCR or qRT-PCR ………..............................................................

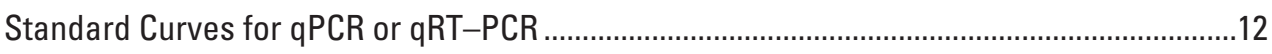

Quality Assurance and Quality Control for Water Samples.......................................................14

Quality Assurance and Quality Control for Viral Pathogens..................................................16

Water-Quality Data for Cedar River and Cedar Rapids Well Fields................................................16

Physical Characteristics, Major lons, and Nutrients...............................................................16

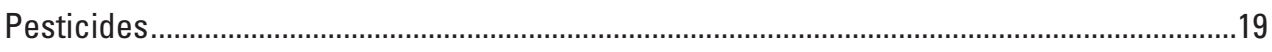

Total Coliforms, Escherichia coli, and Viral Pathogens ......................................................19

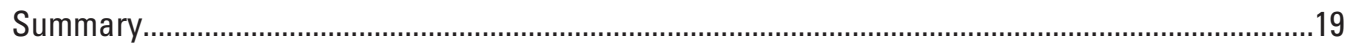

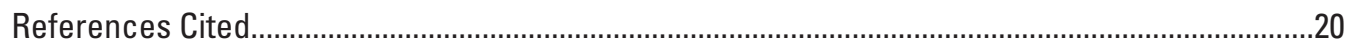

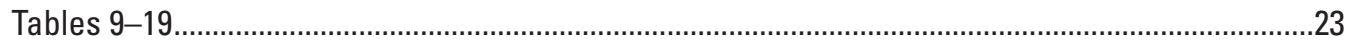

\section{Figures}

1. Map showing sudy area with alluvial well fields and locations of wells, stream sampling sites, and water treatment plants, Cedar Rapids, lowa..

\section{Tables}

1. Information on water-quality data-collection sites, Cedar Rapids, lowa, 2011-17 ..........5

2. Carbon, nutrients, major ions, dissolved solids, and physical characteristics analyzed for in water-quality samples, Cedar Rapids, lowa, 2011-17 ..............................8

3. Select pesticides, degradates, and intermediates analyzed for in water-quality

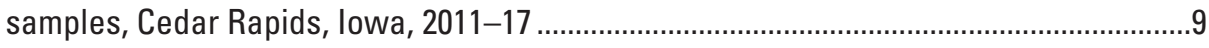

4. Characteristics of viral pathogen analyses, Cedar Rapids, lowa, 2008-17 ....................12

5. Standard curve characteristics for quantitative polymerase chain reaction and quantitative reverse-transcription polymerase chain reaction viral pathogen assays, Cedar Rapids, lowa, 2008-17.

6. Replicate water-quality data for nutrients, carbon, ions, dissolved solids, physical characteristics, and pesticides in groundwater and surface-water samples, Cedar Rapids, lowa, 2011-17. 
7. Surrogate pesticide data for groundwater and surface-water samples with minimum, maximum, and median percent recovery, Cedar Rapids, lowa, 2011-17........17

8. Summary statistics for physical characteristics of groundwater and surface-water samples, for all sites, Cedar Rapids, lowa, 2011-17

9. Summary statistics for major ions and dissolved solids in groundwater and surface-water samples, by site, Cedar Rapids, lowa, 2011-17.

10. Summary statistics for nutrients and dissolved organic carbon in groundwater and surface-water samples, by site, Cedar Rapids, lowa, 2011-17.

11. Summary statistics for nutrients, dissolved organic carbon, and physical characteristics by treatment plant and the wells valved to them, Cedar Rapids, lowa, 2011-17

12. Summary statistics for physical characteristics, major ions, and dissolved solids by treatment plant and the wells valved to them, Cedar Rapids, lowa, 2011-17

13. Description of parent compound pesticides in water-quality samples, Cedar Rapids, lowa, 2011-17.

14. Description of pesticide degradates and intermediates in water-quality samples, Cedar Rapids, lowa, 2011-17.

15. Pesticides sampled for but not detected in water-quality samples, Cedar Rapids, lowa, 2011-17

16. Selected pesticides detected and frequency of detections in groundwater and surface-water samples, by site, Cedar Rapids, lowa, 2011-17.

17. Selected pesticides detected and frequency of detections in groundwater and surface-water samples, by treatment plant and the wells valved to them, Cedar Rapids, lowa, 2011-17.

18. Summary statistics for total coliform and Escherichia coli in groundwater and surface-water samples, by site, Cedar Rapids, lowa, 2011-17.

19. Results for quantitative polymerase chain reaction and quantitative reversetranscription polymerase chain reaction viral pathogen samples, Cedar Rapids, lowa, 2008-17 


\section{Conversion Factors}

U.S. customary units to International System of Units

\begin{tabular}{lcl}
\hline \multicolumn{1}{c}{ Multiply } & \multicolumn{1}{c}{ By } & \multicolumn{1}{c}{ To obtain } \\
\hline inch (in.) & Length & \\
foot (ft) & 2.54 & centimeter $(\mathrm{cm})$ \\
mile (mi) & 0.3048 & meter $(\mathrm{m})$ \\
\hline & 1.609 & kilometer $(\mathrm{km})$ \\
\hline million gallons $(\mathrm{Mgal})$ & Volume & \\
\hline & 3,785 & cubic meter $\left(\mathrm{m}^{3}\right)$ \\
\hline cubic foot per second $(\mathrm{ft} / \mathrm{s})$ & Flow rate & \\
inch per year (in/yr) & 0.02832 & cubic meter per second $\left(\mathrm{m}^{3} / \mathrm{s}\right)$ \\
\hline
\end{tabular}

Temperature in degrees Celsius $\left({ }^{\circ} \mathrm{C}\right)$ may be converted to degrees Fahrenheit $\left({ }^{\circ} \mathrm{F}\right)$ as follows:

$$
{ }^{\circ} \mathrm{F}=\left(1.8 \times{ }^{\circ} \mathrm{C}\right)+32 .
$$

\section{Supplemental Information}

Specific conductance is given in microsiemens per centimeter at 25 degrees Celsius $(\mu \mathrm{S} / \mathrm{cm}$ at $\left.25^{\circ} \mathrm{C}\right)$.

Concentrations of chemical constituents in water are given in either milligrams per liter (mg/L) or micrograms per liter ( $\mu \mathrm{g} / \mathrm{L})$. 


\section{Abbreviations}

$\begin{array}{ll}\text { CAS } & \text { Chemical Abstracts Service } \\ \text { DNA } & \text { deoxyribonucleic acid } \\ \text { EPA } & \text { U.S. Environmental Protection Agency } \\ \text { LoB } & \text { limit of blank } \\ \text { LoD } & \text { limit of detection } \\ \text { LoO } & \text { limit of quantification } \\ \text { LRL } & \text { laboratory reporting limit } \\ \text { OWML } & \text { Ohio Water Microbiology Laboratory } \\ \text { PCR } & \text { polymerase chain reaction } \\ \text { OA } & \text { quality assurance } \\ \text { OC } & \text { quality control } \\ \text { qPCR } & \text { quantitative polymerase chain reaction } \\ \text { qRT-PCR } & \text { quantitative reverse-transcription polymerase chain reaction } \\ \text { RNA } & \text { ribonucleic acid } \\ \text { RPD } & \text { relative percent difference } \\ \text { USGS } & \text { U.S. Geological Survey }\end{array}$




\title{
Selected Water-Quality Data from the Cedar River and Cedar Rapids Well Fields, Cedar Rapids, lowa, 2008-17
}

\author{
By Shannon M. Meppelink, Erin A. Stelzer, Emilia L. Bristow, and Gregory R. Littin
}

\section{Abstract}

The Cedar River alluvial aquifer is the primary source of municipal water in Cedar Rapids, Iowa. Municipal wells are completed in the alluvial aquifer about 40 to 80 feet below land surface. The City of Cedar Rapids and the U.S. Geological Survey have led a cooperative study of the groundwaterflow system and water quality of the aquifer since 1992 . Cooperative reports between the City of Cedar Rapids and the U.S. Geological Survey have documented hydrologic and water-quality data, geochemistry, and groundwater models. Water-quality samples were collected for studies involving well field monitoring, trends, source-water protection, groundwater geochemistry, surface-water-groundwater interaction, and pesticides in groundwater and surface water. Water-quality analyses were completed for major ions (boron, bromide, calcium, chloride, fluoride, iron, magnesium, manganese, potassium, silica, sodium, and sulfate), nutrients (ammonia as nitrogen, ammonia plus organic nitrogen as nitrogen, nitrite plus nitrate as nitrogen, nitrite as nitrogen, orthophosphate as phosphorus, and phosphorus), dissolved organic carbon, selected pesticides, bacteria, and viral pathogens. Physical characteristics (alkalinity, dissolved oxygen, $\mathrm{pH}$, specific conductance, and water temperature) were measured onsite and recorded for each water sample collected. This report presents the results of routine water-quality data-collection activities from water years 2010 through 2017, and additional viral pathogen data from May 2008 to August 2017. A water year is the period from October 1 to September 30 and is designated by the year in which it ends; for example, water year 2015 was from October 1, 2014, to September 30, 2015. Methods of data collection, quality assurance, water-quality analyses, and statistical procedures are presented. Data include the results of water-quality analyses from quarterly sampling from monitoring wells, municipal wells, two water treatment plants, and the Cedar River, as well as monthly nutrient sampling from the Cedar River.

\section{Introduction}

The City of Cedar Rapids, in Linn County, Iowa (fig. 1), obtains its municipal water supply from a shallow alluvial aquifer adjacent to the Cedar River. A total of 45 vertical wells and 5 horizontal collector wells are completed at about 40 to 80 feet (ft) below land surface. Vertical wells gradually are being replaced by higher-yielding horizontal collector wells, but many of the vertical wells are used regularly or are in standby operation. Adequate quantities of generally high-quality potable water have been obtained from the alluvial aquifer since the resource was developed in 1962. Cedar Rapids pumped an average of 37.3 million gallons per day $(\mathrm{Mgal} / \mathrm{d})$ from the alluvial aquifer in $2011,39.6 \mathrm{Mgal} / \mathrm{d}$ in 2012, 37.3 Mgal/d in 2013, 36.9 Mgal/d in 2014, 37.0 Mgal/d in 2015, 36.8 Mgal/d in 2016, and 37.7 Mgal/d in 2017. A record high daily demand was $53.7 \mathrm{Mgal} / \mathrm{d}$ on July 25, 2012, and the month of July 2012 had record production at 1,538.6 Mgal/d (T. Baloch, City of Cedar Rapids Water Department, written commun., January 2018). The higher demands in 2012 are most likely due to the drought of 2012 (Mallya and others, 2013). To document the quality of water available from the Cedar River and the alluvial aquifer, the City of Cedar Rapids and the U.S. Geological Survey (USGS) have led a cooperative study of the groundwater-flow system, surface-water system, and water quality in and near the well fields since 1992.

\section{Previous Investigations}

Results from the long-term cooperative study have been documented in several reports. Schulmeyer (1995) analyzed the effect of contributions from the Cedar River on the quality of groundwater near the municipal well fields. Schnoebelen and Schulmeyer (1996) documented hydrogeologic data collected and compiled from October 1992 to March 1996. Schulmeyer and Schnoebelen (1998) described the hydrogeology near the municipal well fields, documented a groundwater-flow model constructed to simulate regional groundwater flow under steady-state conditions, identified sources of water to the municipal well fields, and assessed temporal and spatial variations of selected water-quality constituents and properties. Boyd (1998) characterized groundwater flow near the 


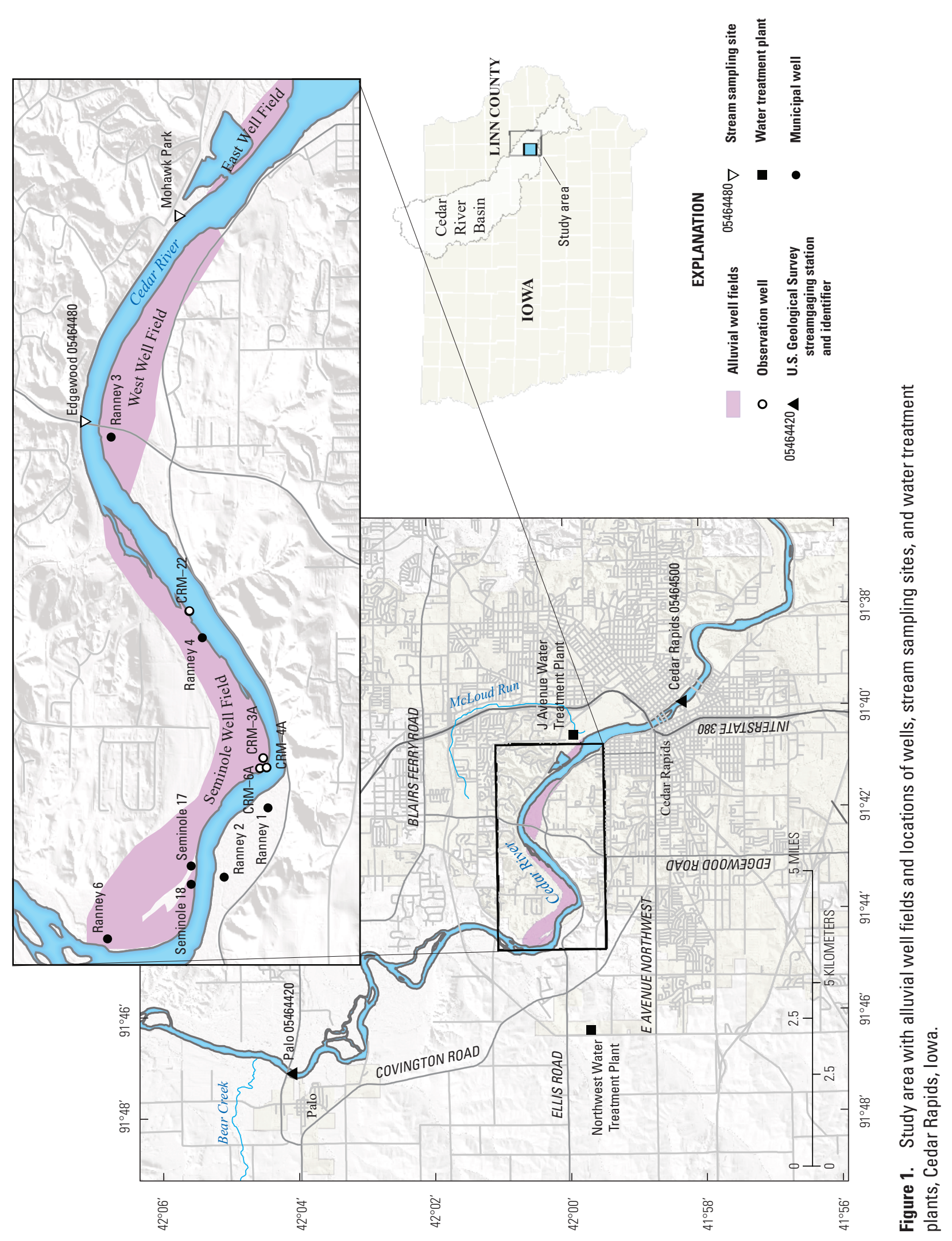


municipal well fields using selected environmental isotopes and tracers. Boyd (2000) evaluated the occurrence and distribution of concentrations of selected pesticides in the alluvial aquifer and Cedar River after springtime application of these pesticides to upstream cropland areas. Boyd and others (1999) further documented hydrogeologic data collected in the Cedar Rapids area from April 1996 to March 1999. Water-quality data collected in the Cedar Rapids area from calendar years 1999 to 2005 was documented by Littin and Schnoebelen (2010) and from calendar years 2006 to 2010 by Littin (2012). Most recently, a report by Kalkhoff (2018) documents the changes in nutrient transport in the Cedar River Basin from water years $2000-15$, as well as the variable transport from subbasins.

\section{Purpose and Scope}

This report presents the results of water-quality datacollection activities from May 2008 through August 2017 for a study completed by the USGS, in cooperation with the City of Cedar Rapids, Iowa. Data presented in this report include results of water-quality analyses and physical characteristics of water samples measured from samples collected from the Cedar River, the 2 Cedar Rapids water treatment plants, 4 monitoring wells, and 11 municipal wells in the Cedar Rapids municipal well fields. This report is the third data report in a series. Previous reports documented water-quality data collected in the Cedar Rapids area from calendar years 1999 to 2005 by Littin and Schnoebelen (2010) and calendar years 2006 to 2010 by Littin (2012).

\section{Description of the Study Area}

Cedar Rapids is located in Linn County in east-central Iowa. Municipal water for the city of Cedar Rapids is supplied from three well fields (Seminole, East, and West) along the Cedar River (fig. 1). The city of Cedar Rapids had a population of about 126,300 in 2010, and the U.S. Census Bureau projected it to be 131,127 in July 2016 (U.S. Census Bureau, 2018). The Cedar River Basin drains an area of 6,510 square miles $\left(\mathrm{mi}^{2}\right)$ upstream from the streamgaging station at Cedar Rapids (Cedar River at Cedar Rapids, Iowa, USGS station 05464500 , fig. 1). Upstream land use is more than 80 percent agriculture, mostly corn and soybean production with some pasture land, hay, and small grains (Iowa Department of Natural Resources, 2006). Median annual precipitation for 2011 to 2017 was 37.13 inches (in.) per year at the Cedar Rapids Municipal Airport (Midwestern Regional Climate Center, 2018). Extreme daily mean flows recorded at the streamgaging station during this reporting period were 80,700 cubic feet per second $\left(\mathrm{ft}^{3} / \mathrm{s}\right)$ on September 27, 2016, and $268 \mathrm{ft}^{3} / \mathrm{s}$ on December 22, 2012 (U.S. Geological Survey, 2018). Extreme daily mean flows recorded during 1903-2010 were $138,000 \mathrm{ft}^{3} / \mathrm{s}$ on June 13, 2008, and $140 \mathrm{ft}^{3} / \mathrm{s}$ on November 18, 1989 (U.S. Geological Survey, 2018).
Hydrogeologic units in and near the Cedar Rapids well fields include unconsolidated surficial sediment layers of loess, glacial till, and Cedar River alluvium (alluvial aquifer), underlain by carbonate bedrock composed of several formations ranging from Silurian to Devonian in age (Iowa Department of Natural Resources, 2004). The Cedar River flood plain ranges from about 1,000 to $3,300 \mathrm{ft}$ wide in the study area and is bounded by steep bluffs that rise nearly $200 \mathrm{ft}$ above the river valley, exposing carbonate bedrock in some places. The upland topography is characterized by rolling hills of low relief typically formed in loess and glacial till. The alluvial aquifer ranges from 5 to $95 \mathrm{ft}$ thick near the well fields, with the thickest parts nearest to the present-day location of the Cedar River and the thinnest alluvium adjacent to the valley walls. The alluvial aquifer is characterized by a sequence of coarse sand and gravel at the base, grading upward to fine sand, silt, and clay near the surface. The carbonate bedrock in the study area consists primarily of jointed and fractured limestone and dolomite, with interbeds of chert and shale (Schulmeyer and Schnoebelen, 1998). The 22 lithologic formations ranging from Silurian to Devonian in age have a maximum thickness of about $700 \mathrm{ft}$ in the study area, and although no municipal wells have been completed in this aquifer, it is used locally for private and industrial water supply (University of Iowa, 2013; Tucci and McKay, 2005; Iowa Department of Natural Resources, 2004). The unconsolidated surficial layers of the Cedar River Valley, underlying Devonian and Silurian carbonate bedrock, and deeper hydrogeologic units are described in detail by Hansen (1970), Wahl and Bunker (1986), and Schulmeyer and Schnoebelen (1998).

The Cedar River is in direct hydraulic connection with the alluvial aquifer (Turco and Buchmiller, 2004), and the alluvial aquifer is recharged by infiltration from the river, as well as by precipitation and seepage from underlying and adjacent hydrogeologic units. In areas affected by municipal pumping, groundwater flows from the Cedar River toward the well fields, whereas in other areas, groundwater generally flows toward the river (Hansen, 1970; Schulmeyer, 1995; R. Hesemann, Cedar Rapids Water Department, oral commun., March 2007; Littin and Schnoebelen, 2010).

\section{Methods of Study}

Samples for water-quality analysis were collected from the Cedar River, observation wells within the alluvial well fields, municipal wells, and the two Cedar Rapids water treatment plants. Data include results of water-quality analyses and physical characteristics measured at the time of sample collection. Well locations used for sampling are shown in figure 1. Summary statistics (minimum, maximum, and median) were compiled for all water-quality samples. Data in this report were retrieved from the USGS National Water Information System database (U.S. Geological Survey, 2018) and were complete as of August 15, 2018. In addition, methods of 
Selected Water-Quality Data from the Cedar River and Cedar Rapids Well Fields, Cedar Rapids, lowa, 2008-17

quality assurance (QA) of samples are discussed, and data on quality-control (QC) samples are presented.

\section{Well Construction and Nomenclature}

Wells sampled during the study included 2- and 4-in. diameter monitoring wells. The monitoring wells were installed using hollow-stem auger drilling techniques (Hackett, 1987) and completed with polyvinyl-chloride (PVC) flushjoint casing. Bentonite grout was installed around the casing 6 to $8 \mathrm{ft}$ below land surface, and the wells were capped with a cement pad at the surface. Well depths ranged from 18 to $97 \mathrm{ft}$. Well-construction information for all monitoring wells is listed in table 1.

Monitoring wells are named according to a convention that includes the year the well was installed (for example, 1993), the agency identifier (USGS), the local project identifier, (CRM, for Cedar Rapids Municipal), and a unique incremental number (beginning with 1). For example, well 1993USGS CRM-3 is the third monitoring well installed by the USGS for the CRM project. For convenience in this report, the year and agency identifier typically will not be included when referring to a site name. With the exception of Edgewood Ranney 3, municipal wells used by the City of Cedar Rapids are identified by the well field name (Seminole), then the well number (for example, Seminole 17). In addition, horizontal collector wells are identified as "Ranney" wells.

\section{Water-Quality Sampling}

Water-quality samples were collected from the Cedar River, 2- and 4-in. diameter observation wells, municipal wells, and the two Cedar Rapids water treatment plants (multiple municipal wells per treatment plant were composited for raw-water composites) on a quarterly basis from October 2010 through August 2017. Quarterly samples consisted of field parameters, nutrients, carbon, common ions, and pesticides. Beginning in May 2008, routine viral pathogen samples and bacteria (total coliform and Escherichia coli) were also included in the quarterly sampling at 12 of the 17 sites included in this report.

This reporting period was one of transition for many of the sites sampled. For most of this period, water-quality samples were collected from the Cedar River downstream from the Seminole wellfield at either the Cedar River at Edgewood Road at Cedar Rapids, Iowa, (USGS station 05464480) or downstream at a jetty at Mohawk Park. Mohawk Park is about 1 river mile downstream from the Edgewood Road Bridge. Starting in September 2016, the sample collection location was moved about 11 miles (mi) upstream from the city to the Cedar River at Blairs Ferry Road at Palo, Iowa, streamgaging station (USGS station 05464420, hereafter referred to as "Palo"). The first sample collected at Palo was a flood sample, which included the full suite of quarterly sample compounds, plus suspended sediment and bacteria; subsequent samples were either the full suite of compounds regularly collected for the quarterly sample or monthly nutrient-only samples. For the Palo site, there was 1 single flood sample, 4 quarterly samples, and 7 nutrient-only samples. Samples at the Edgewood site ceased when sampling at Palo started. Other changes include the cessation of sampling at CRM-22 because the well was lost to the river during high flows in 2011; CRM-4 was also lost in high flows and was replaced with CRM-4A, near the original well. During quarterly sampling, a single alluvial monitoring well was sampled; for consistency, CRM-4A is the preferred well for sampling, but CRM-3A is sampled if CRM4A is either inaccessible or physically impaired. Seminole 18 is a municipal well that was regularly offline for the City of Cedar Rapids and unavailable to sample, so sampling ceased there in 2016. During the period covered in this report, three sites were added into the quarterly sampling effort. A monitoring well finished in the Silurian-Devonian aquifer was added in 2010, and Ranney 6 came online in 2014. Both have been regularly sampled since; however, CRM-6A is only sampled annually. Also added into the project was the Northwest Water Treatment Plant. As with the treatment plant on J Avenue, Northwest Water Treatment Plant raw water is sampled for physical properties, nutrients, pesticides, carbon, major ions, and pathogens; finished water is only sampled for pathogens.

The two treatment plants have different operating capacities, and the number of wells sampled by the USGS per plant is not equal. The Northwest Water Treatment Plant operates at roughly half the capacity of the J Avenue plant. The J Avenue plant has a maximum daily output capacity of $40 \mathrm{Mgal} / \mathrm{d}$; the Northwest Water Treatment Plant maximum daily output capacity is $20 \mathrm{Mgal} / \mathrm{d}$. Of the municipal wells sampled for this project, Ranney 1, 2, and 6, and Seminole 17 and 18 are valved to the Northwest Water Treatment Plant. Ranneys 3 and 4 are valved to the J Avenue plant. As necessary, Ranney 6 can be valved to the J Avenue plant instead of the Northwest Water Treatment Plant for water-quality or water quantity issues (J. Donaghy, City of Cedar Rapids Water Department, written commun., February 2018). For the purposes of this report, as Ranney 6 is typically valved to the Northwest Water Treatment Plant, data for Ranney 6 are included in the aggregated data tables for the Northwest Water Treatment Plant.

Before collecting water-quality samples, monitoring wells were pumped to remove about three borehole volumes of water. Water samples were collected using a stainless-steel submersible Fultz pump and chemically inert fluoropolymer tubing. Onsite measurements of air temperature, air pressure, alkalinity, dissolved oxygen, $\mathrm{pH}$, specific conductance, and water temperature were collected at the time of sample collection. Dissolved oxygen, $\mathrm{pH}$, specific conductance, and water temperature were measured in a flow-through chamber for all sites except Palo. Field measurements at Palo were collected at multiple equidistant points across the width of the river using a multiparameter sonde suspended into the river from the bridge. All field measurements were taken using a multiparameter Yellow Springs Incorporated 6920, YSI EXO2, Eureka Manta 2, or a Eureka Manta 35 sonde. 


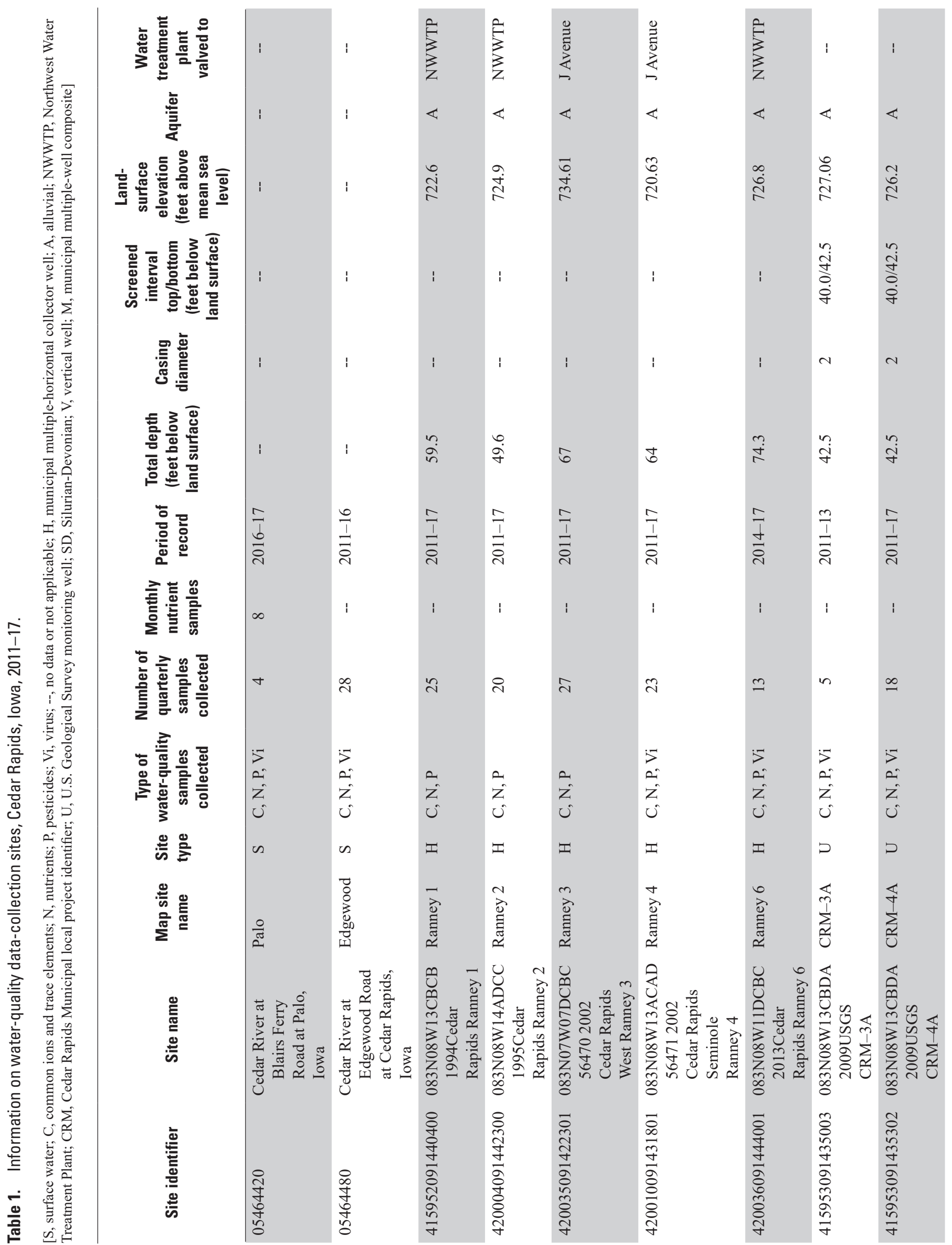




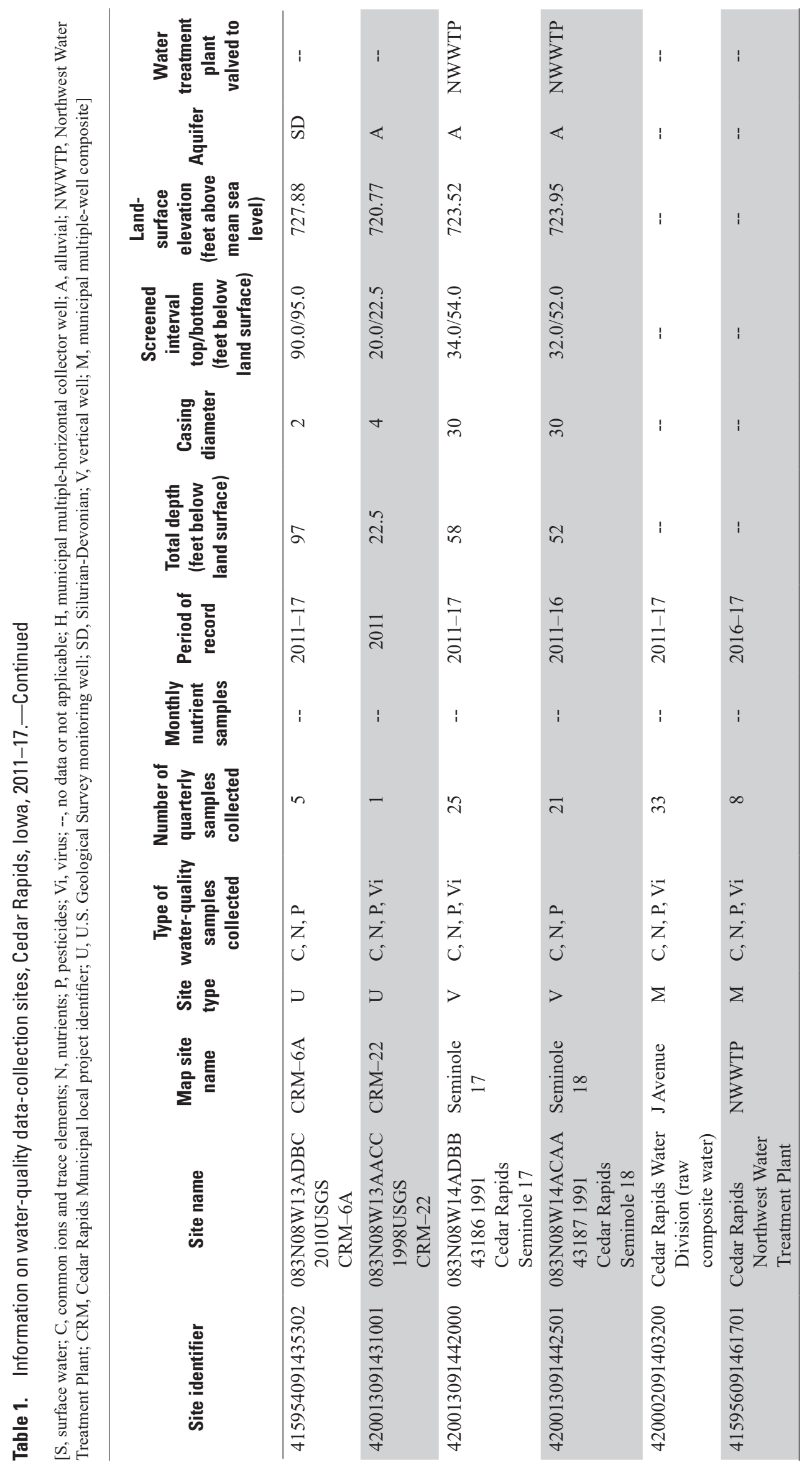


Water samples for analysis of nutrients and major ions were filtered through a 0.45 -micrometer $(\mu \mathrm{m})$ pore size polycarbonate disk or capsule filter in the field. Water samples for pesticide analysis were filtered through a 142-millimeter (mm) or 47-mm diameter, $0.7-\mu \mathrm{m}$ pore size, borosilicate glassfiber filter baked at 450 degrees Celsius $\left({ }^{\circ} \mathrm{C}\right)$ and placed in a stainless-steel or fluoropolymer filter unit. After collection, water samples were kept chilled until shipping by overnight air express to the USGS National Water-Quality Laboratory in Denver, Colorado, for analysis.

Samples were collected according to USGS protocols (U.S. Geological Survey, variously dated), with the following adaptations. Groundwater samples and Cedar River samples collected at Mohawk Park were processed with exposure to the atmosphere without a sampling chamber by one person to maintain sampling consistency across the history of the project. Cedar River samples collected at Palo were collected and processed using clean hands/dirty hands techniques requiring two individuals with assigned operations to minimize potential sources of contamination. As indicated in the "Quality Assurance and Quality Control" section of this report, the adaptation for groundwater sampling did not adversely affect the samples.

\section{Chemical Laboratory Analysis}

Nutrient concentrations were analyzed by colorimetric methods (Patton and Kryskalla, 2011) for dissolved species and alkaline persulfate digestion (Patton and Kryskalla, 2003) for unfiltered samples. Analytical methods used for major ions are described by Fishman (1993). Inductively coupled plasma-atomic emission spectrometry was used to determine boron concentrations (Struzeski and others, 1996). The high-temperature combustion method was used to determine the total organic carbon concentration in samples (Standard Methods for the Examination of Water and Wastewater, 2018). Pesticide samples collected from 2008 to 2016 were analyzed for 25 compounds including select degradates and intermediates (USGS schedule 1379) with solid-phase extraction and capillary-column gas chromatography/mass spectrometry methods (Sandstrom and others, 1992). A newer C-18 solidphase extraction and gas chromatography/mass spectrometry method (Sandstrom and others, 2001) that resulted in lower reporting limits for more than 80 compounds (USGS schedule 2033) was used for analysis of pesticide samples collected in 2017. Select constituents tested for in water-quality samples are listed in table 2 for carbon, nutrients, physical characteristics, and major ions and table 3 for pesticides and select degradates and intermediates. The National Water Information System parameter codes, the Chemical Abstracts Service (CAS) Registry Number $\AA$, laboratory reporting limits (LRL), and reporting units are listed in tables 2 and 3. This report contains CAS Registry Numbers, which are registered trademarks of the American Chemical Society. CAS recommends the verification of the CAS Registry Numbers through CAS Client Services ${ }^{\mathrm{SM}}$. The LRL is used to specify the lowest quantifiable value for constituents listed in tables 2 and 3 . The LRLs for many of the constituents varied during the period of record covered by this report; the range per constituent is listed in table 2 . In this period of record, the pesticide schedule, or grouping of analytes, routinely used for this project was discontinued by the USGS National Water-Quality Laboratory, necessitating the change in June 2016 to a schedule with a broader range of constituents. The overlap in pesticide schedules and change in LRLs are noted in table 3.

\section{Sample Concentration for Viral Pathogens}

Water samples collected from May 2008 to August 2015 for viral pathogen analyses were filtered through a ViroCap encapsulated filter (Scientific Methods, Granger, Indiana). Samples collected from September 2015 to September 2017 were filtered through a REXEED-25S ultrafilter (Asahi Kasei Medical Company, Tokyo, Japan). Sample filters were capped and shipped overnight on ice to the USGS Ohio Water Microbiology Laboratory (OWML) in Columbus, Ohio, for analysis.

Upon arrival at the OWML, filters were eluted and eluates were concentrated before deoxyribonucleic acid/ribonucleic acid (DNA/RNA) extraction. Samples received between May 2008 and September 2012 were eluted using an OptimaRE elution solution (Scientific Methods, Granger, Ind.) and were concentrated using a precipitation protocol described by Lambertini and others (2008). Samples received between October 2012 and May 2016 were eluted using 1.5-percent Beef Extract (Becton, Dickinson and Company, Franklin Lakes, New Jersey) at pH 9.0 and concentrated via organic flocculation according to U.S. Environmental Protection Agency (EPA) Method 1615 (Fout and others, 2014). Samples received between June 2016 and August 2017 were eluted using a 0.075-percent Tween 20/25 millimolar (mM) Tris High Volume Elution foam canister (InnovaPrep LLC, Drexel, Missouri) and concentrated using a Centricon Plus-70 centrifugal filter (EMD Millipore, Billerica, Massachusetts). See table 4 for all changes to viral pathogen analyses by sample date.

\section{DNA/RNA Extraction and qPCR or qRT-PCR}

Viral DNA and RNA were extracted from sample concentrates using the QIAamp® DNA Blood Mini Extraction Kit (Qiagen, Valencia, California) according to manufacturer's instructions, except the AVL viral lysis buffer with the addition of carrier RNA (Qiagen, Valencia, Calif.) was used instead of the AL general lysis buffer. Sample extracts were stored at $-70^{\circ} \mathrm{C}$ until batch analysis was performed.

For analysis of adenovirus DNA by quantitative polymerase chain reaction ( $\mathrm{qPCR}$ ), the primers/probe and polymerase chain reaction (PCR) conditions described by Jothikumar and others (2005a) were followed. For analysis of enterovirus and norovirus (GIA and GII) RNA by quantitative reverse-transcription polymerase chain reaction (qRT-PCR) 
Table 2. Carbon, nutrients, major ions, dissolved solids, and physical characteristics analyzed for in water-quality samples, Cedar Rapids, lowa, 2011-17.

[This report contains Chemical Abstracts Service Registry Numbers ${ }^{\circledR}$, which are a registered trademark of the American Chemical Society. The Chemical Abstracts Service recommends the verification of the Registry Numbers through Chemical Abstracts Service Client Services ${ }^{\mathrm{SM}}$. CASRN, Chemical Abstracts Service Registry Number ${ }^{\circledR}$; LRL, laboratory reporting level; --, not applicable; mg/L, milligram per liter; N, nitrogen; P, phosphorus; $\mu \mathrm{g} / \mathrm{L}$, microgram per liter; $\mathrm{C}$, Celsius; $\mathrm{mmHg}$, millimeter mercury; $\mu \mathrm{S} / \mathrm{cm}$, microsiemens per centimeter]

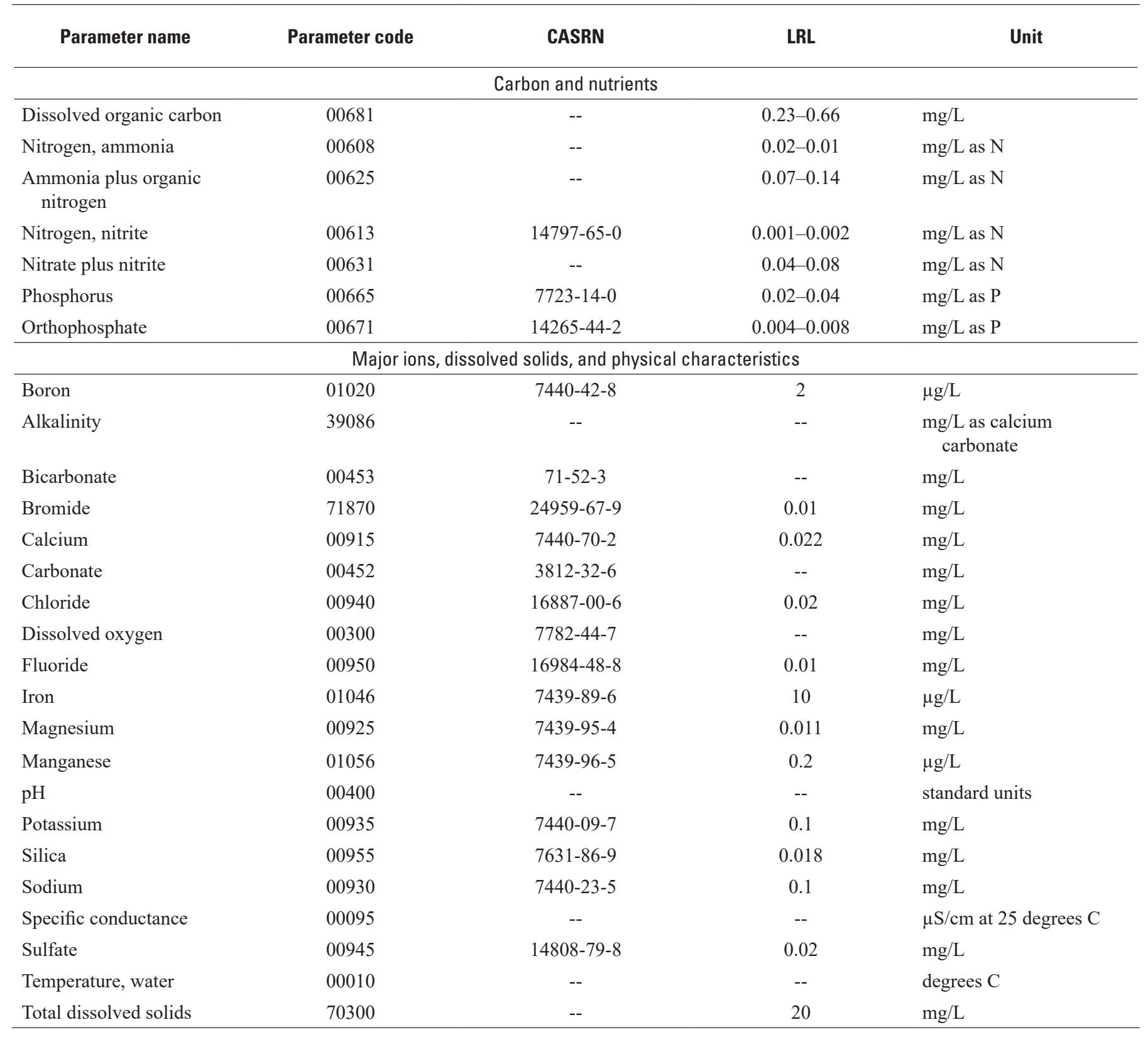


Table 3. Select pesticides, degradates, and intermediates analyzed for in water-quality samples, Cedar Rapids, lowa, 2011-17.

[This report contains Chemical Abstracts Service Registry Numbers ${ }^{\circledR}$, which are a registered trademark of the American Chemical Society. The Chemical Abstracts Service recommends the verification of the Registry Numbers through Chemical Abstracts Service Client Services ${ }^{\mathrm{SM}}$. CASRN, Chemical Abstracts Service Registry Number®; LRL, laboratory reporting level; $\mu \mathrm{g} / \mathrm{L}$, microgram per liter; --, not applicable]

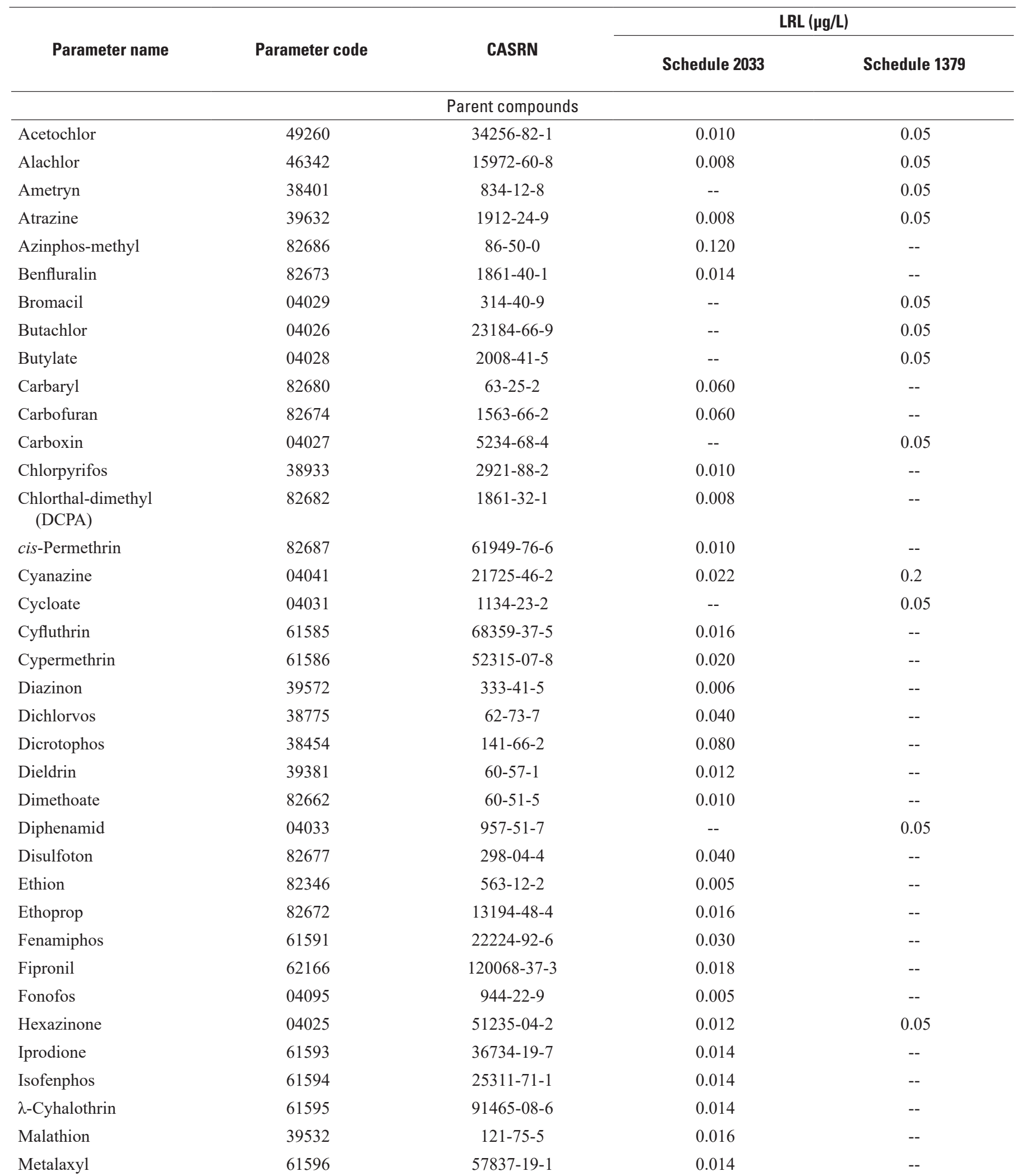


Table 3. Select pesticides, degradates, and intermediates analyzed for in water-quality samples, Cedar Rapids, lowa, 2011-17.Continued

[This report contains Chemical Abstracts Service Registry Numbers ${ }^{\circledR}$, which are a registered trademark of the American Chemical Society. The Chemical Abstracts Service recommends the verification of the Registry Numbers through Chemical Abstracts Service Client Services ${ }^{\mathrm{SM}}$. CASRN, Chemical Abstracts Service Registry Number®; LRL, laboratory reporting level; $\mu \mathrm{g} / \mathrm{L}$, microgram per liter; --, not applicable]

LRL $(\mu \mathrm{g} / \mathrm{L})$

Parameter name

Methidathion

Methyl parathion

Metolachlor

Metribuzin

Molinate

Myclobutanil

Oxyfluorfen

Pendimethalin

Phorate

Phosmet

Prometon

Prometryn

Propachlor

Propanil

Propargite

Propazine

Propyzamide

$S$-Ethyl

dipropylthiocarbamate

(EPTC)

Simazine

Simetryn

Tebuconazole

Tebuthiuron

Tefluthrin

Terbacil

Terbufos

Terbuthylazine

Thiobencarb

Tribufos

Trifluralin

Trifluralin

Vernolate
Parameter code $\quad$ CASRN

61598
82667
39415
82630
82671
61599
61600
82683
82664
61601
04037
04036
04024
82679
82685
38535
82676
82668

04035

04030

62852

82670

61606

04032

82675

04022

82681

61610

04023

82661

04034

950-37-

2212-67-1

298-02-2

732-11-6

1610-18-0

7287-19-6

1918-16-7

709-98-8

2312-35-8

139-40-2

759-94-4

122-34-9

1014-70-6

5902-51-2

5915-41-3

78-48-8

1582-09-8

1582-09-8

1929-77-7
51218-45-2

21087-64-9

88671-89-0

42874-03-3

40487-42-1

23950-58-5

107534-96-3

34014-18-1

79538-32-2

13071-79-9

28249-77-6

Degradates

Degradates

61618

04040

2-Chloro-4-isopropylamino-6-amino- $S$-triazine (CIAT)

6967-29-9

6190-65-4
Schedule 2033

Schedule 1379

$\begin{array}{cc}0.012 & -- \\ 0.008 & -- \\ 0.012 & 0.05 \\ 0.012 & 0.05 \\ 0.008 & -- \\ 0.010 & -- \\ 0.010 & -- \\ 0.012 & - \\ 0.020 & - \\ 0.140 & -- \\ 0.012 & -- \\ 0.010 & 0.05 \\ -- & 0.05 \\ 0.010 & 0.05 \\ 0.020 & -- \\ -- & -- \\ 0.008 & 0.05 \\ 0.006 & -- \\ & --\end{array}$

$0.006 \quad 0.05$

$--\quad 0.05$

0.020

0.028

0.014

$--$

0.05

0.018

0.008

0.016

0.018

--

0.05

0.018

$-$

$--$

0.05

0.050

$--$

0.010

0.010

0.05 
Table 3. Select pesticides, degradates, and intermediates analyzed for in water-quality samples, Cedar Rapids, lowa, 2011-17.Continued

[This report contains Chemical Abstracts Service Registry Numbers ${ }^{\circledR}$, which are a registered trademark of the American Chemical Society. The Chemical Abstracts Service recommends the verification of the Registry Numbers through Chemical Abstracts Service Client Services ${ }^{\text {SM }}$. CASRN, Chemical Abstracts Service Registry Number ${ }^{2}$; LRL, laboratory reporting level; $\mu \mathrm{g} / \mathrm{L}$, microgram per liter; --, not applicable]

$\operatorname{LRL}(\mu \mathrm{g} / \mathrm{L})$

Parameter name
Parameter code

61627

Chlorpyrifos oxygen analog
cis-Propiconazole

Desulfinylfipronil

Desulfinylfipronil amide

Diazoxon

Disulfoton sulfone

Endosulfan sulfate

Ethion monoxon

Fenamiphos sulfone

Fenamiphos sulfoxide

Fipronil sulfide

Fipronil sulfone

Malaoxon

Methyl paraoxon

Phorate oxygen analog

Phosmet oxygen analog

Terbufos oxygen analog sulfone

trans-Propiconazole

79846

62170

62169

61638

61640

61590

61644

61645

61646

62167

62168

61652

61664

61666

61668

61674

79847

2,6-Diethylaniline

2-Ethyl-6-methylaniline

3,4-Dichloroaniline

61620

61625
61633

34362

61635

61636

Intermediates

626-43-7

1570-64-5

959-98-8

961-22-8

$5598-15-2$

$112721-87-6$

$$
--
$$$$
--
$$

$962-58-3$

2497-06-5

1031-07-8

$17356-42-2$

31972-44-8

31972-43-7

120067-83-6

120068-36-2

1634-78-2

950-35-6

2600-69-3

3735-33-9

56070-15-6

120523-07-1

579-66-8

24549-06-2
Schedule 2033

Schedule 1379 


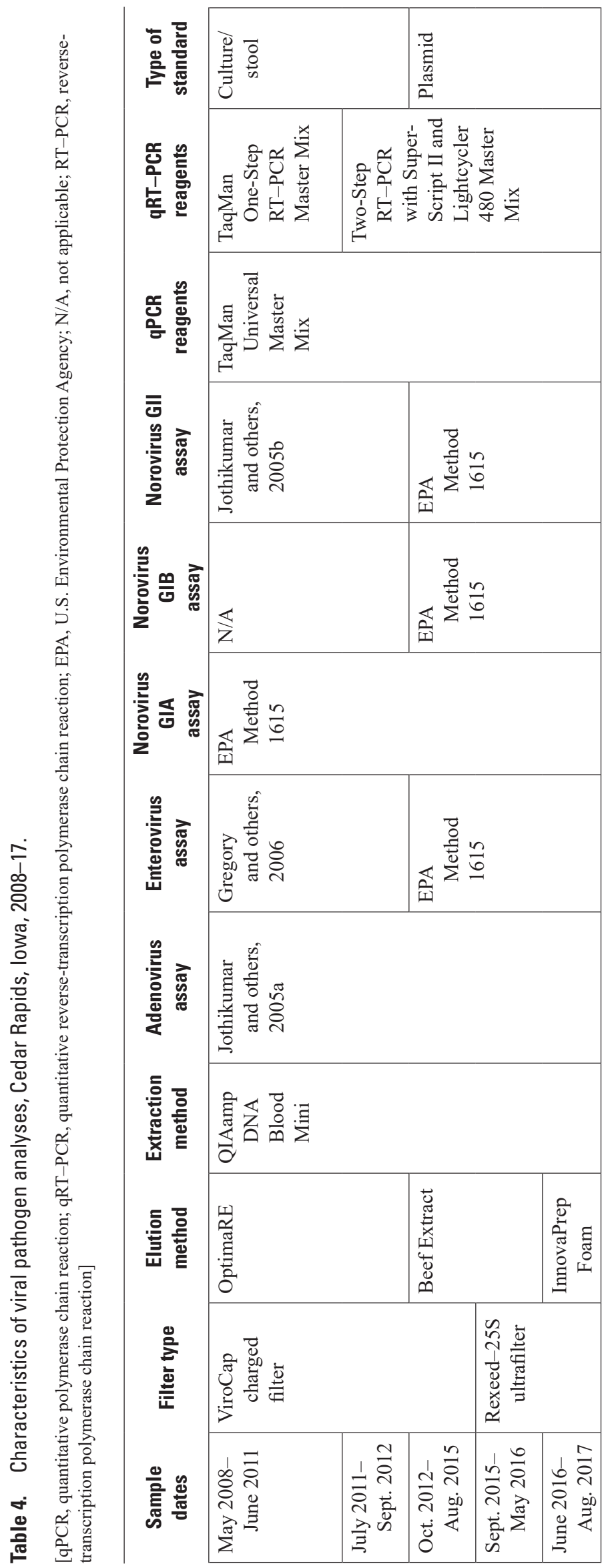

from May 2008 to September 2012, the primers/probe and PCR conditions described in Gregory and others (2006) and Jothikumar and others (2005b), respectively, were followed. From October 2012 to August 2017, the primers/probe and PCR conditions described in EPA Method 1615 (Fout and others, 2014) were followed for the analysis of enterovirus and norovirus GIA and GII by qRT-PCR. A norovirus GIB assay described in EPA Method 1615 was also added at this time. All samples were run in duplicate on an Applied Biosystems ${ }^{\circledR} 7500$, StepOne Plus ${ }^{\mathrm{TM}}$, or Quant Studio ${ }^{\mathrm{TM}} 3$ (Foster City, Calif.) thermal cycler. TaqMan ${ }^{\circledR}$ Universal Master Mix (Applied Biosystems, Foster City, Calif.) was used for all qPCR reactions. From May 2008 to June 2011, TaqMan ${ }^{\circledR}$ One-Step RT-PCR Master Mix (Applied Biosystems, Foster City, Calif.) was used for all qRT-PCR reactions. Starting in July 2011, a two-step reverse-transcription reaction was used for all qRT-PCR reactions: the first step used SuperScript ${ }^{\mathrm{TM}}$ II Reverse Transcriptase (Invitrogen, Carlsbad, Calif.), and the second step used Lightcycler ${ }^{\circledR} 480$ Master Mix (Roche Diagnostics, Risch-Rotkreuz, Switzerland) with the addition of ROX ${ }^{\mathrm{TM}}$ reference dye (Applied Biosystems, Foster City, Calif.).

Sample inhibition for qPCR was determined by seeding an aliquot of the sample extract with an extracted positive control target in a duplicate qPCR reaction. Sample inhibition for qRT-PCR was determined by seeding an aliquot of the sample extract with hepatitis $G$ virus armored RNA ${ }^{\circledR}$ (Asuragen, Inc, Austin, Texas). The concentration of target in the sample was then compared to the concentration of target in a clean matrix control (molecular grade water) that was seeded with the same extracted positive control/hepatitis G virus target. Sample extracts were considered inhibited and were diluted if the seeded test sample was more than two threshold cycles higher than that of the seeded clean matrix control.

\section{Standard Curves for qPCR or qRT-PCR}

For qPCR and qRT-PCR methods, standard curves are required to assign test samples with a relative quantity of an analyte. From May 2008 to September 2012, standard curves for adenovirus and enterovirus viral pathogen targets were created using virus stocks treated with Benzonase ${ }^{\circledR}$ (Novagen, Madison, Wisconsin) as described previously (Francy and others, 2011). Human noroviruses are not culturable; therefore, standard curves for norovirus GIA and GII viral pathogen targets were created using a positive stool sample obtained from the Ohio Department of Health in Reynoldsburg, Ohio. Stool was treated with Vertrel XF (Miller-Stephenson, Danbury, Connecticut) and concentrated via centrifugation. Norovirus GII was in the stool sample at high enough concentrations to create a six-point standard curve; however, the stool sample contained low concentrations of GIA, and a complete curve was not obtained until the OWML changed to the more sensitive two-step reverse-transcription reaction. Starting in October 2012, plasmid standards for all viral pathogen 
targets were used to create standard curves. Plasmids were constructed by insertion of PCR-amplified target sequences into a pCR4 TOPO ${ }^{\circledR}$ Escherichia coli (E. coli) plasmid vector (Invitrogen, Carlsbad, Calif.). Plasmid DNA was extracted and purified from E. coli cells using the QuickLyse ${ }^{\mathrm{TM}}$ Miniprep Kit (Qiagen, Valencia, Calif.). Plasmid sequences were verified by DNA sequencing at the Ohio State University Plant-Microbe Genomics Facility. The copy number was calculated from DNA concentration measured using the PicoGreen ${ }^{\circledR}$ assay (Invitrogen, Carlsbad, Calif.) and the molecular weight of the plasmid.

Guidelines for interpreting standard curve data are available in the Applied Biosystems ${ }^{\circledR}$ StepOne ${ }^{\mathrm{TM}}$ and StepOne Plus $^{\mathrm{TM}}$ Real-Time PCR Systems Reagent Guide (Applied Biosystems, 2010). Standard curve characteristics are listed in table 5. The dynamic range describes the lowest and highest standards analyzed by the laboratory for each assay in copies per PCR reaction. The amplification efficiency of the PCR should be $90-110$ percent; an efficiency of 100 percent means an exact doubling of the target DNA sequence at each cycle.

The limit of blank (LoB), limit of detection (LoD), and limit of quantification (LoQ) were calculated for each assay. The LoB is the lowest concentration that can be reported with 95-percent confidence to be above the concentrations of blanks, and it is used because low-level cross contamination may exist during sample manipulation. Also, anecdotal evidence of the occurrence of autofluorescence for some of the assays has been documented. The LoD is the lowest concentration that can be detected with 95-percent confidence that it is a true detection and can be distinguished from the LoB. The LoD was determined by running a series of dilutions of the target with a minimum of 10 replicates per dilution (except for the norovirus GIA stool LoD, which only had 4 replicates because of the problems with the stool mentioned previously). The dilutions used varied depending on the magnitude of the lowest standard concentration used in the standard curve for that target. The dilution with the lowest concentration of target that met the following requirements was chosen as the LoD:

(1) standard deviation of the replicates was less than 1 and (2) the number of replicates with detections was greater than 95 percent. If the $\mathrm{LoB}$ is higher than the calculated LoD, then the LoB is used as the LoD. The LoQ is the lowest concentration of a target that can be accurately quantified. The LoQ is calculated from the standard deviation of the $\mathrm{LoD}$ and is, therefore, higher than the $\mathrm{LoD}$. LoB, $\mathrm{LoD}$, and $\mathrm{LoQ}$ values are initially threshold cycle values, converted to and reported as copies per reaction volume by use of an assay-specific standard curve. Sample results are reported as estimated (denoted with an "E") when duplicate reaction results for a sample did not agree. Sample results less than the LoQ but greater than the LoD are reported as estimated with the additional qualifier of "b," meaning concentration is extrapolated below the LoQ. The qualifier " $\mathrm{t}$ " is reported when the analyte is detected and the concentration is greater than the LoB but less than the LoD. Results qualified with a " $t$ " have greater uncertainty than those qualified with a "b." If an analyte is detected but less than one copy per reaction, it is reported as less than the sample reporting limit. Because original sample volumes and dilutions to overcome inhibition were often different for each sample or set of samples, the LoD was applied on a sampleby-sample basis to sample reporting limits. The sample reporting limits are the "less-than values" for each sample and assay and are reported as copies per liter.

Table 5. Standard curve characteristics for quantitative polymerase chain reaction (qPCR) and quantitative reverse-transcription polymerase chain reaction viral pathogen assays, Cedar Rapids, lowa, 2008-17.

[Dynamic range and limit of detection are reported in copies per reaction; $R^{2}$, coefficient of determination; N/A, not applicable]

\begin{tabular}{|c|c|c|c|c|c|c|}
\hline qPCR assay & $\begin{array}{c}\text { Total number of } \\
\text { curves run }\end{array}$ & Dynamic range & $\begin{array}{l}\text { Amplification } \\
\text { efficiency } \\
\text { (percent) }\end{array}$ & $R^{2}$ value & $\begin{array}{l}\text { Limit of detection } \\
\text { (culture, plasmid) }\end{array}$ & $\begin{array}{c}\text { Limit of } \\
\text { quantification } \\
\text { (culture, plasmid) }\end{array}$ \\
\hline Adenovirus & 13 & $3.20-8.29 \times 10^{7}$ & $90-101$ & $0.993-1.00$ & $6.4,36$ & 10,100 \\
\hline Enterovirus & 24 & $1.83-4.26 \times 10^{7}$ & $91-109$ & $0.992-1.00$ & 11,38 & 22,66 \\
\hline Norovirus GIA & 19 & $1.90-4.26 \times 10^{7}$ & $96-110$ & $0.991-1.00$ & 16,24 & 25,59 \\
\hline Norovirus GIB & 18 & $3.08-4.26 \times 10^{7}$ & $92-105$ & $0.990-1.00$ & N/A, 29 & N/A, 74 \\
\hline Norovirus GII & 21 & $3.54-4.26 \times 10^{7}$ & $91-104$ & $0.990-1.00$ & 25,35 & 41,110 \\
\hline
\end{tabular}




\section{Quality Assurance and Quality Control for Water Samples}

To properly interpret water-quality data and to verify that these data are reliable and accurate, QA procedures and QC samples are needed. In general, QA includes using correct procedures and protocols, proper documentation (log books and field sheets), and approved USGS analytical methods, as documented in the "Chemical Laboratory Analysis" section, excepting for the experimental viral methods whose QA/QC are detailed further below. The QC samples typically are used in the estimation of the magnitude of bias and variability of the environmental samples. Bias is systematic error that can "skew" results in either a positive or negative direction. The most common source of positive bias in water-quality studies is contamination of samples from airborne gases and particulates, or inadequate cleaning of sampling equipment between uses and locations. Variability is the degree of random error of independent measurements of the sample quantity. Variability may be the result of errors in laboratory analytical procedures or in collection of samples in the field. The QA/QC procedures are required to ensure that the data collected meet standards of reliability and accuracy.

The QA/QC procedures for the study followed USGS protocols (U.S. Geological Survey, variously dated) and other USGS guidelines (Mueller and others, 1997). About 10 percent of the environmental samples collected for the study were analyzed for QC including equipment blanks, field blanks, and replicates. Generally, blanks are used to estimate sample bias whereas replicates are used to estimate sample variability.

A blank is a water sample that is intended to be free of the analytes of interest. Two types of commercially available blank waters were used for equipment and field blanks. The water is considered to be organic blank water or inorganic blank water and is certified by the manufacturer (Ricca) to be free of either organic compounds (organic blank water) or inorganic compounds (inorganic blank water). For equipment blanks, blank water was passed through all sampling equipment in a "clean environment," such as the laboratory, to examine the cleanliness of the equipment before sampling. A field blank is a specific type of blank sample collected in the field and is used to demonstrate that (1) equipment has been adequately cleaned to remove contamination introduced by samples obtained at the previous site; (2) sample collection and processing have not resulted in contamination; and (3) sample handling, transport, and laboratory analysis have not introduced contamination (Mueller and others, 1997). Field blank samples of the organic blank water and inorganic blank water were collected by passing the water through all pumps, filter plates, and filters to verify the cleanliness of sampling equipment and technique. Field blanks were collected by water type on separate dates.

Replicates are two or more samples collected or processed so that the samples are almost identical in composition. All replicate samples were collected as sequential samples in that they were collected one after the other, using the same techniques and filters as necessary. For the purposes of this report, the terms "environmental sample" and "replicate sample" are used to identify a particular sample in a replicate pair.

One objective of collecting replicate pairs was to estimate the precision of constituent concentrations determined by sample processing and analysis. Analytical results of organic constituents generally are more variable than those of inorganic constituents. Replicate pairs were compared using relative percent differences (RPDs). The RPD between sample pairs was calculated using the following:

$$
R P D=|S 1-S 2| /(S 1+S 2 / 2) \times 100
$$

where

$S 1 \quad$ is equal to the concentration of a single detected constituent in the environmental sample, in micrograms per liter or milligrams per liter; and

$S 2 \quad$ is equal to the concentration of a single detected constituent in the replicate sample, in the same units as $S 1$.

A large RPD indicates greater variability between the environmental and replicate samples. Where detections were in both samples, variability for constituents in the replicate samples was generally within 10 percent of the environmental samples. As shown in table 6, the RPD for nutrients and dissolved organic carbon ranged from 0 to 77.3 percent; the RPD for common ions, dissolved solids, and physical characteristics ranged from 0 to 42.4 percent; and the RPD for pesticides ranged from 0 to 117 percent. It should be noted that when comparing low concentrations (within about 10 times the detection limit) between replicate pairs, the RPD can seem large because slight differences (common at the lowest detection levels) can result in higher RPDs. This was the case for individual RPDs that had the largest percentage (10 percent or greater) for this period of record. For nutrients, four RPDs larger than 10 percent all had absolute values of less than 0.013 milligram per liter (mg/L). For pesticides, five RPDs larger than 10 percent all had absolute values of less than 0.05 microgram per liter $(\mu \mathrm{g} / \mathrm{L})$. When one of the pairs had analytical results less than the reporting limit (considered a nondetect) and the other had a value greater than the reporting limit, the value of the nondetect was considered to be one-half that of the reporting limit and the RPD was calculated as such. The RPDs for these cases were much greater than all other RPDs and were included in the data table.

Surrogates were added to all environmental and QC samples for pesticide analysis before sample preparation in the laboratory. A surrogate has physical and chemical properties similar to those of the analytes of interest but is not normally in environmental samples. Surrogates provide QC by monitoring matrix effects and gross processing errors (Wershaw and others, 1987) and help control for bias, either positive or negative. Surrogate recoveries of organic chemicals are expressed in percent and for this data set range from 33.2 to 
Table 6. Replicate water-quality data for nutrients, carbon, ions, dissolved solids, physical characteristics, and pesticides in groundwater and surface-water samples, Cedar Rapids, lowa, 2011-17.

[mg/L, milligram per liter; $\mathrm{N}$, nitrogen; $\mu \mathrm{g} / \mathrm{L}$, microgram per liter; $\mathrm{P}$, phosphorus; $\mathrm{CaCO}_{3}$, calcium carbonate; $\mathrm{SiO}_{2}$, silicon dioxide]

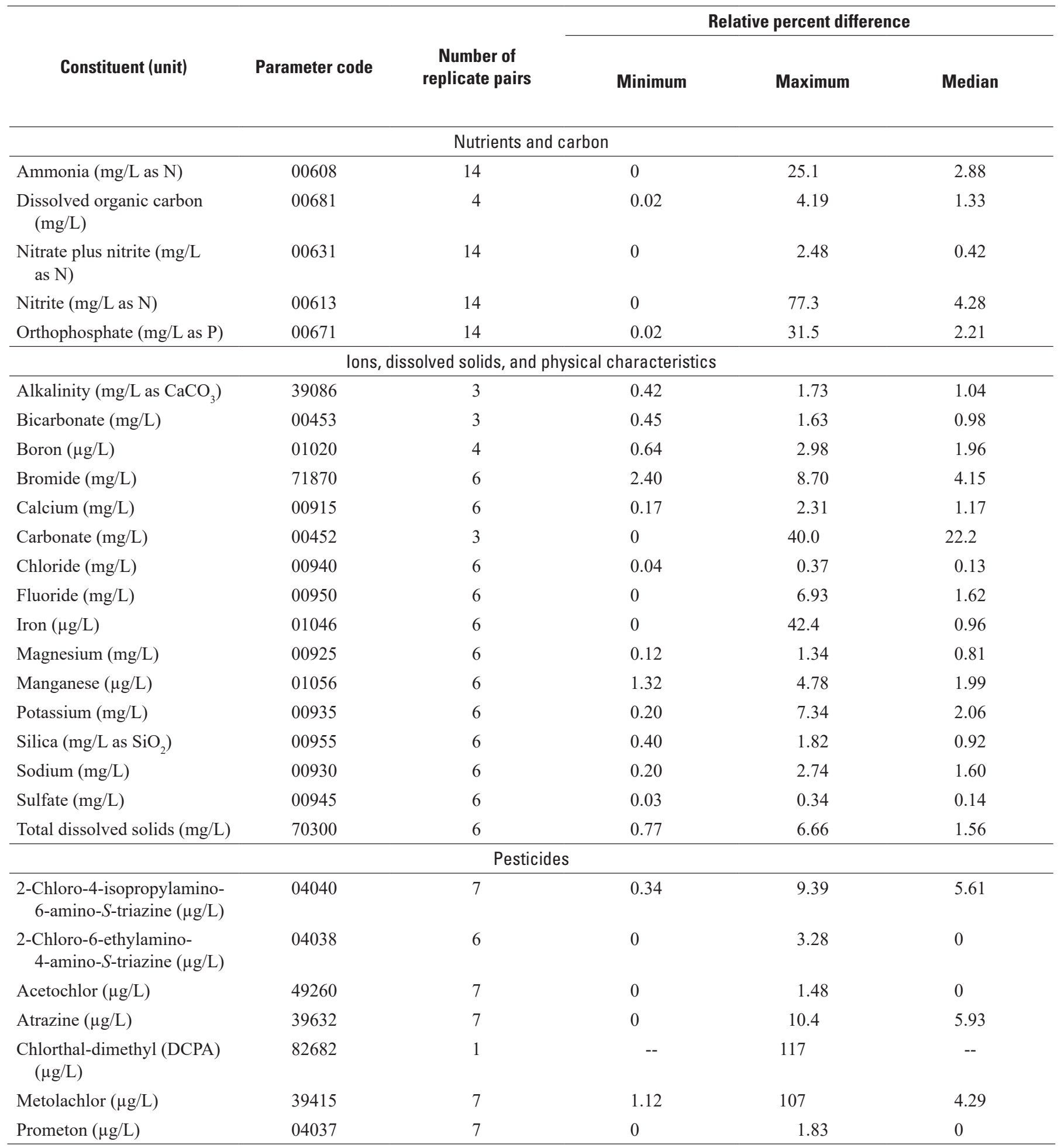


140.1 percent and are listed in table 7. Surrogate recoveries that consistently are less than 70 percent may indicate that many targeted compounds may be in greater concentrations than reported. Median surrogate percent recoveries (ranging from 52.0 to 100.7 percent) are listed in table 7. Analyte concentrations are not adjusted for surrogate recoveries.

\section{Quality Assurance and Quality Control for Viral Pathogens}

Laboratory analytical QC samples included filtered positive and negative controls, extraction negative controls, as well as separate PCR positive and negative controls run on each qPCR or qRT-PCR plate. Filtered positive control samples were spiked with enterovirus. Each sample was assayed in duplicate by qPCR or qRT-PCR. All filtered negative controls, extraction negative controls, and PCR negative controls were less than the detection limit except for one extraction negative control. Samples analyzed at the same time as this extraction negative control were reextracted and reanalyzed later, with the exception of one sample, which did not have sufficient volume to reanalyze, so the LoB was used as the LoD for this sample. Enterovirus was detected in all filtered positive controls, and the appropriate target was detected in all PCR positive controls.

Field QC samples for viral pathogens consisted of 1 field blank, 3 replicates, and 1 seeded matrix control. The field blank sample consisted of 10 liters (L) of sterile, deionized water treated in the same manner as a regular filtered sample at the sampling location and was negative for all viruses. Replicates were collected concurrently using a Y-valve and a second filtration apparatus. There were no detections for any of the targets in any of the replicate samples; therefore, an RPD could not be determined. The seeded matrix control was collected from a representative groundwater well to determine the recovery of viruses through all processing and analytical steps. The sample was filtered onsite, but the last $10 \mathrm{~L}$ were collected in a cubitainer and shipped with the filter to the OWML. At the OWML, the 10-L cubitainer was seeded with enterovirus to achieve a target seed amount of 106 viruses, estimated by the OWML by use of a RiboGreen assay. The seeded 10-L cubitainer was then filtered through the same filter that was used onsite for that sample and eluted as described above. An unseeded control was analyzed in conjunction with the seeded matrix control to determine background concentrations of enteroviruses. Enterovirus was recovered from the spiked sample at 6.40 percent, which is within the acceptance criterion according to EPA Method 1615 section 14.2.5 (Fout and others, 2014).

\section{Water-Quality Data for Cedar River and Cedar Rapids Well Fields}

The results of the water-quality samples collected from October 2010 through August 2017 are summarized in tables 8 to 19 at the back of this report. Data compiled are from samples collected from the Cedar River, municipal wells, observation wells, and the two water treatment plants with quarterly monitoring. Other water-quality data were obtained from monthly nutrient sampling on the Cedar River.

Water-quality data were used to assess the quality of water in the alluvial aquifer, Silurian-Devonian aquifer, and the Cedar River. The Cedar River is the primary influencer on water quality in the alluvial aquifer because of induced infiltration from the river as a result of the pumping of wells (Schulmeyer and Schnoebelen, 1998; Boyd, 2000; Turco and Buchmiller, 2004). Agricultural chemicals (nutrients and pesticides) are of concern because of the predominance of agricultural land use (90 percent and greater) in the Cedar River Basin. An 11.6-mi reach of the Cedar River between the confluence with Bear Creek, which is upstream from Palo, and the confluence with McLoud Run in Cedar Rapids is identified on the Iowa Department of Natural Resources Water Quality Assessments Impaired Waters List for nitrate, $\mathrm{pH}$, and E. coli impairment (Iowa Department of Natural Resources, 2006; fig. 1). For this segment of the Cedar River, a Total Maximum Daily Load limit was established for nitrate by Iowa Department of Natural Resources and approved by the EPA in January 2007 (Iowa Department of Natural Resources, 2006); a bacteria Total Maximum Daily Load was approved by the EPA in February 2010 (U.S. Environmental Protection Agency, 2010). Water-quality data were also evaluated for nutrients, pesticides, selected major ions, selected viruses, and physical characteristics.

\section{Physical Characteristics, Major Ions, and Nutrients}

Physical characteristics were measured at each sampling site when a water-quality sample was collected. Physical characteristics generally obtained for samples include dissolved oxygen (in milligrams per liter), $\mathrm{pH}$ (in standard $\mathrm{pH}$ units), specific conductance (in microsiemens per centimeter at $25^{\circ} \mathrm{C}$ ), water temperature (in degrees Celsius), alkalinity (in milligrams per liter as calcium carbonate), bicarbonate (in milligrams per liter), carbonate (in milligrams per liter), air pressure (in millimeters of mercury), and air temperature (in degrees Celsius). Summary statistics for dissolved oxygen, $\mathrm{pH}$, specific conductance, water temperature, alkalinity, bicarbonate, and carbonate of sample water from individual sites are listed in table 8 .

Major ion data were compiled for boron, bromide, calcium, chloride, fluoride, iron, magnesium, manganese, potassium, silica, sodium, and sulfate in milligrams per liter, 


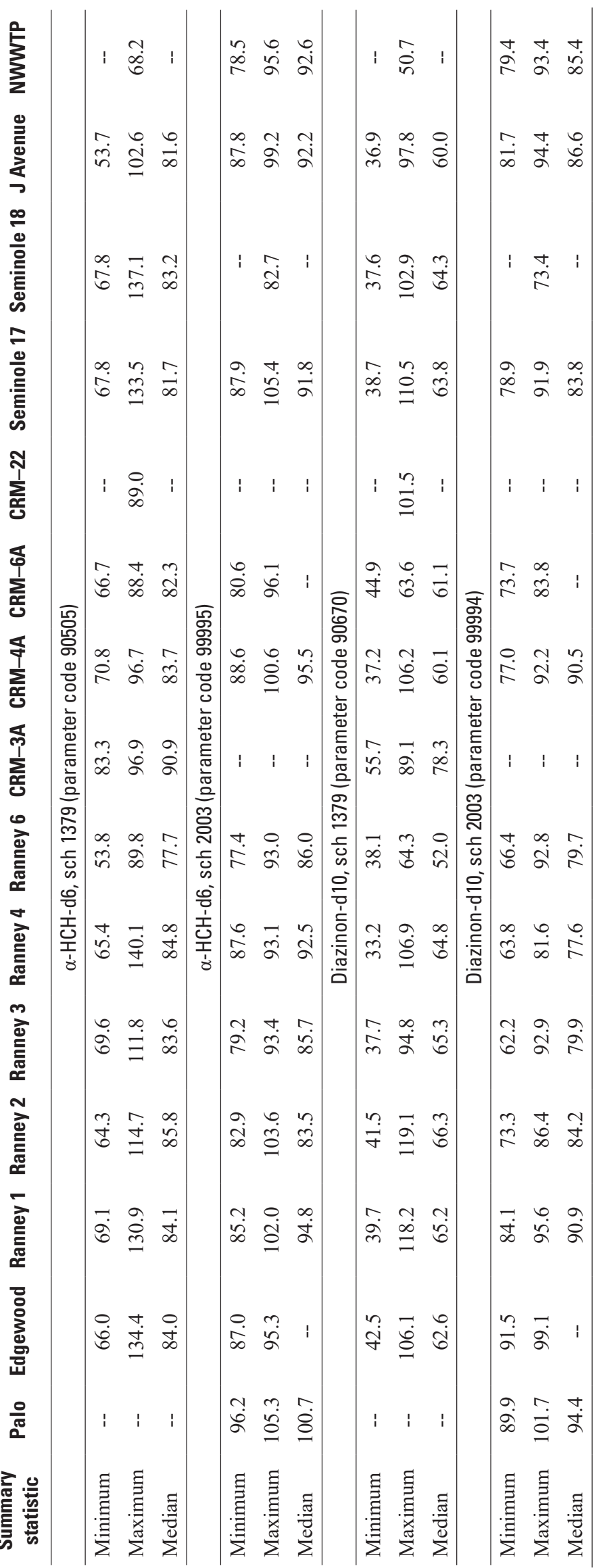




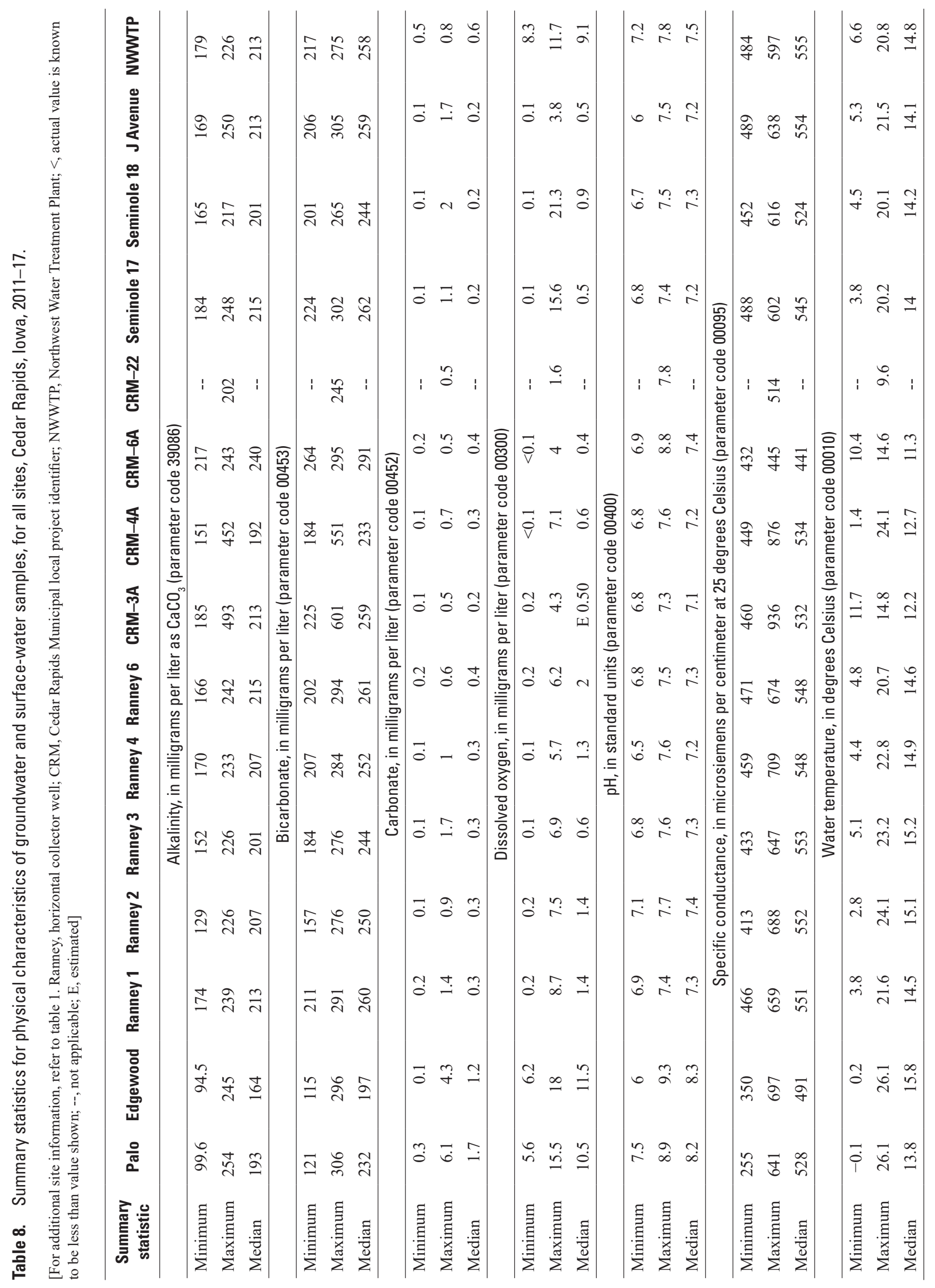


except for boron, iron, and manganese, which were collected in micrograms per liter. Major ion data are required for characterization of the water chemistry and geochemical modeling. Summary statistics for major ions for all sites are listed in table 9 (at the back of this report).

Nutrient data, in milligrams per liter, were compiled for ammonia as nitrogen, ammonia plus organic nitrogen as nitrogen, nitrite plus nitrate as nitrogen, nitrite as nitrogen, orthophosphate as phosphorus, and phosphorus. Dissolved organic carbon data, in milligrams per liter, are summarized with nutrient data. Nutrient summary statistics for groundwater and surface water from all sites are shown in table 10 (at the back of this report).

Summary statistics for nutrients, dissolved organic carbon, and physical characteristics for the treatment plants and the wells valved to them are summarized in table 11 (at the back of this report). Summary statistics for physical characteristics, major ions, and dissolved solids for the treatment plants and the wells valved to them are summarized in table 12 (at the back of this report).

\section{Pesticides}

Pesticides are used to control unwanted vegetation, insects, and other pests in agricultural and urban areas. Typically, large amounts (thousands of pounds per year) of common herbicides are applied during the growing season in the Cedar River Basin to corn and soybean crops (Schnoebelen and others, 2003). In 2012, the most recent pesticide use data available, glyphosate, acetochlor, atrazine, and metolachlor were the most commonly used herbicides in Iowa (U.S. Geological Survey, 2017). Insecticides are detected less often in water, most likely because they are used in smaller amounts than herbicides, have short persistence, and are applied during periods of reduced runoff (Schnoebelen and others, 2003). Pesticide degradates are formed when a parent pesticide compound breaks down or degrades. Pesticide degradates often have been detected at higher concentrations than their parent compounds (Kolpin and others, 2000, 2004; Schnoebelen and others, 2003). The pesticide degradates of atrazine, 2-Chloro4-ethylamino-6-amino-S-triazine (CEAT) and 2-Chloro4-amino-6-isopropyl-amino-S-triazine (CIAT), were among the 24 degradates analyzed. Degradates are included in the tables listing pesticides analyzed. Parent compound pesticides sampled during the study period and their uses are listed in table 13 (at the back of this report). Pesticide degradates and intermediates sampled during the study period are listed in table 14 (at the back of this report). Pesticides that were tested for but not detected are listed in table 15 (at the back of this report). Pesticides detected in water samples from individual sites are listed in table 16 (at the back of this report). Summary statistics for pesticides for the treatment plants and the wells valved to them are summarized in table 17 (at the back of this report).

\section{Total Coliforms, Escherichia coli, and Viral Pathogens}

Of the sites sampled during this period of record, 12 were sampled for enteric viruses, total coliforms, and E. coli. Those sites were CRM-4A, CRM-3A, CRM-22, Seminole 17, Ranney 4, Ranney 6, J Avenue Water Treatment Plant (raw and finished waters), Northwest Water Treatment Plant (raw and finished waters), Cedar River at Edgewood Road, and Palo. Results for total coliform and E. coli for these sites are listed in table 18 (at the back of this report). Results for viral pathogens are listed in table 19 (at the back of this report).

\section{Summary}

The Cedar River alluvial aquifer is the primary source of municipal water in Cedar Rapids, Iowa. Municipal wells are completed in the alluvial aquifer about 40 to 80 feet below land surface. The City of Cedar Rapids and the U.S. Geological Survey have led a cooperative study of the groundwaterflow system and water quality of the aquifer since 1992. Cooperative reports between the City of Cedar Rapids and the U.S. Geological Survey have documented hydrologic and water-quality data, geochemistry, and groundwater models. Water-quality samples were collected for studies involving well field monitoring, trends, source-water protection, groundwater geochemistry, surface-water-groundwater interaction, and pesticides in groundwater and surface water. Water-quality analyses were completed for major ions (boron, bromide, calcium, chloride, fluoride, iron, magnesium, manganese, potassium, silica, sodium, and sulfate), nutrients (ammonia as nitrogen, ammonia plus organic nitrogen as nitrogen, nitrite plus nitrate as nitrogen, nitrite as nitrogen, orthophosphate as phosphorus, and phosphorus), dissolved organic carbon, selected pesticides, bacteria, and viral pathogens. Physical characteristics (alkalinity, dissolved oxygen, $\mathrm{pH}$, specific conductance, and water temperature) were measured onsite and recorded for each water sample collected. This report presents the results of routine water-quality data-collection activities from water years 2010 through 2017, and additional viral pathogen data from May 2008 to August 2017. A water year is the period from October 1 to September 30 and is designated by the year in which it ends; for example, water year 2015 was from October 1, 2014, to September 30, 2015. Methods of data collection, quality assurance, water-quality analyses, and statistical procedures are presented. Data include the results of water-quality analyses from quarterly sampling from observation wells, municipal wells, two water treatment plants, and the Cedar River, as well as monthly nutrient sampling from the Cedar River. 


\section{References Cited}

Applied Biosystems, 2010, Applied Biosystems StepOne and StepOne Plus real-time PCR systems: Applied Biosystems Reagent Guide, accessed February 26, 2019, at https://assets.thermofisher.com/TFS-Assets/LSG/manuals/ cms_046739.pdf.

Boyd, R.A., 1998, Characterizing ground water flow in the municipal well fields of Cedar Rapids, Iowa, with selected environmental tracers: Journal of the American Water Resources Association, v. 34, no. 3, p. 507-518. [Also available at https://doi.org/10.1111/j.1752-1688.1998.tb00950.x.]

Boyd, R.A., 2000, Herbicides and herbicide degradates in shallow groundwater and the Cedar River near a municipal well field, Cedar Rapids, Iowa: Science of the Total Environment, v. 248, no. 2-3, p. 241-253. [Also available at https://doi.org/10.1016/S0048-9697(99)00546-X.]

Boyd, R.A., Kuzniar, R.L., and Schulmeyer, P.M., 1999, Selected hydrologic data from the Cedar Rapids area, Linn County, Iowa, April 1996 through March 1999: U.S. Geological Survey Open File Report 99-461, 214 p. [Also available at https://doi.org/10.3133/ofr99461.]

Fishman, M.J., ed., 1993, Methods of analysis by the U.S. Geological Survey National Water Quality LaboratoryDetermination of inorganic and organic constituents in water and fluvial sediments: U.S. Geological Survey OpenFile Report 93-125, 217 p. [Also available at https://doi. org/10.3133/ofr93125.]

Fout, S., Brinkman, N., Cashdollar, S., Griffin, S., McMinn, B., Rhodes, E., Varughese, E., Karim, M., Grimm, A., Spencer, S., and Borchardt, M., 2014, Method 1615 measurement of enterovirus and norovirus occurrence in water by culture and RT-qPCR (ver. 1.3, Sept. 2014): Washington D.C., U.S. Environmental Protection Agency, 99 p.

Francy, D.S., Stelzer, E.A., Bushon, R.N., Brady, A.M.G., Mailot, B.E., Spencer, S.K., Borchardt, M.A., Elber, A.G., Riddell, K.R., and Gellner, T.M., 2011, Quantifying viruses and bacteria in wastewater-Results, interpretation, methods, and quality control: U.S. Geological Survey Scientific Investigations Report 2011-5150, 44 p. [Also available at https://doi.org/10.3133/sir20115150.]

Gregory, J.B., Litaker, R.W., and Noble, R.T., 2006, Rapid one-step quantitative reverse transcriptase PCR assay with competitive internal positive control for detection of enteroviruses in environmental samples: Applied and Environmental Microbiology, v. 72, no. 6, p. 3960-3967. [Also available at https://doi.org/10.1128/AEM.02291-05.]
Hackett, G., 1987, Drilling and constructing monitoring wells with hollow-stem augers, part 1-Drilling considerations: Groundwater Monitoring and Remediation, v. 7, no. 4, p. $51-62$.

Hansen, R.E., 1970, Geology and groundwater resources of Linn County, Iowa: Iowa Geological Survey Water-Supply Bulletin no. 10, 66 p.

Iowa Department of Natural Resources, 2004, Stratigraphic column of Iowa: Geological Survey Iowa Department of Natural Resources, accessed October 23, 2018, at http:// publications.iowa.gov/4862/1/EM-40.pdf.

Iowa Department of Natural Resources, 2006, Total maximum daily load for nitrate, Cedar River, Linn County, Iowa: Iowa Department of Natural Resources, Watershed Improvement Section, 55 p., accessed April 2018 at http://www.iowadnr. gov/portals/idnr/uploads/water/watershed/tmdl/files/final/ cedarriver.pdf.

Jothikumar, N., Cromeans, T.L., Hill, V.R., Lu, X., Sobsey, M.D., and Erdman, D.D., 2005a, Quantitative real-time PCR assays for detection of human adenoviruses and identification of serotypes 40 and 41: Applied and Environmental Microbiology, v. 71, no. 6, p. 3131-3136. [Also available at https://doi.org/10.1128/AEM.71.6.3131-3136.2005.]

Jothikumar, N., Lowther, J.A., Henshilwood, K., Lees, D.N., Hill, V.R., and Vinjé, J., 2005b, Rapid and sensitive detection of noroviruses by using TaqMan-based one-step reverse transcription-PCR assays and application to naturally contaminated shellfish samples: Applied and Environmental Microbiology, v. 71, no. 4, p. 1870-1875. [Also available at https://doi.org/10.1128/AEM.71.4.1870-1875.2005.]

Kalkhoff, S.J., 2018, Transport of nitrogen and phosphorus in the Cedar River Basin, Iowa and Minnesota, 2000-15: U.S. Geological Survey Scientific Investigations Report 20185090, 44 p., accessed July 2018 at https://doi.org/10.3133/ $\operatorname{sir} 20185090$.

Kolpin, D.W., Thurman, E.M., and Linhart, S.M., 2000, Finding minimal herbicide concentrations in ground water? Try looking for their degradates: Science of the Total Environment, v. 248, no. 2-3, p. 115-122. [Also available at https:// doi.org/10.1016/S0048-9697(99)00535-5.]

Kolpin, D.W., Schnoebelen, D.J., and Thurman, E.M., 2004, Degradates provide insight to spatial and temporal trends of herbicides in ground water: Groundwater, v. 42, no. 4, p. 601-608. [Also available at https://doi. org/10.1111/j.1745-6584.2004.tb02628.x.] 
Lambertini, E., Spencer, S.K., Bertz, P.D., Loge, F.J., Kieke, B.A., and Borchardt, M.A., 2008, Concentration of enteroviruses, adenoviruses, and noroviruses from drinking water by use of glass wool filters: Applied and Environmental Microbiology, v. 74, no. 10, p. 2990-2996. [Also available at https://doi.org/10.1128/AEM.02246-07.]

Littin, G.R., 2012, Selected water-quality data from the Cedar River and Cedar Rapids well fields, Cedar Rapids, Iowa, 2006-10: U.S. Geological Survey Data Series 657, 32 p. [Also available at https://doi.org/10.3133/ds657.]

Littin, G.R., and Schnoebelen, D.J., 2010, Selected waterquality data from the Cedar River and Cedar Rapids well fields, Cedar Rapids, Iowa, 1999-2005: U.S. Geological Survey Data Series 494, 52 p. [Also available at https://doi. org/10.3133/ds494.]

Mallya, G., Zhao, L., Song, X.C., Niyogi, D., and Govindaraju, R.S., 2013, 2012 Midwest drought in the United States: Journal of Hydraulic Engineering, v. 18, no. 7, p. $737-745$.

Midwestern Regional Climate Center, 2018, Annual data summary Cedar Rapids Municipal AP (IA) USW00014990: Midwestern Regional Climate Center digital data, accessed January 2018 at https://mrcc.illinois.edu/.

Mueller, D.K., Martin, J.D., and Lopes, T.J., 1997, Qualitycontrol design for surface-water sampling in the National Water-Quality Assessment Program: U.S. Geological Survey Open-File Report 97-223, 17 p. [Also available at https://doi.org/10.3133/ofr97223.]

Patton, C.J., and Kryskalla, J.R., 2003, Methods of analysis by the U.S. Geological Survey National Water Quality Laboratory_Evaluation of alkaline persulfate digestion as an alternative to Kjeldahl digestion for determination of total and dissolved nitrogen and phosphorus in water: U.S. Geological Survey Water-Resources Investigations Report 2003-4174, 33 p. [Also available at https://pubs.er.usgs. gov/publication/wri034174.]

Patton, C.J., and Kryskalla, J.R., 2011, Colorimetric determination of nitrate plus nitrite in water by enzymatic reduction, automated discrete analyzer methods: U.S. Geological Survey Techniques and Methods, book 5, chap. B8, 34 p. [Also available at https://pubs.usgs.gov/tm/05b08/.]

Sandstrom, M.W., Stroppel, M.E., Foreman, W.T., and Schroeder, M.P., 2001, Methods of analysis by the U.S. Geological Survey National Water Quality Laboratory-Determination of moderate-use pesticides and selected degradates in water by C-18 solid-phase extraction and gas chromatography/mass spectrometry: U.S. Geological Survey WaterResources Investigations Report 2001-4098, 70 p. [Also available at https://doi.org/10.3133/wri20014098.]
Sandstrom, M.W., Wydoski, D.S., Schroeder, M.P., Zamboni, J.L., and Foreman, W.T., 1992, Methods of analysis by the U.S. Geological Survey National Water Quality Laboratory-Determination of organonitrogen herbicides in water by solid-phase extraction and capillary-column gas chromatography/mass spectrometry with selected-ion monitoring: U.S. Geological Survey Open-File Report 91-519, 26 p. [Also available at https://doi.org/10.3133/ofr91519.]

Schnoebelen, D.J., Kalkhoff, S.J., Becher, K.D., and Thurman, E.M., 2003, Water-quality assessment of the Eastern Iowa Basins - Selected pesticides and pesticide degradates in streams, 1996-98: U.S. Geological Survey Water-Resources Investigations Report 2003-4075, 62 p. [Also available at https://doi.org/10.3133/wri034075.]

Schnoebelen, D.J., and Schulmeyer, P.M., 1996, Selected hydrogeologic data from the Cedar Rapids area, Benton and Linn Counties, Iowa, October 1992 through March 1996: U.S. Geological Survey Open File Report 96-471, 172 p. [Also available at https://doi.org/10.3133/ofr96471.]

Schulmeyer, P.M., 1995, Effect of the Cedar River on the quality of ground-water supply for Cedar Rapids, Iowa: U.S. Geological Survey Water-Resources Investigations Report 94-4211, 68 p. [Also available at https://doi.org/10.3133/ wri944211.]

Schulmeyer, P.M., and Schnoebelen, D.J., 1998, Hydrogeology and water quality in the Cedar Rapids area, Iowa, 1992-96: U.S. Geological Survey Water-Resources Investigations Report 97-4261, 77 p. [Also available at https:// pubs.usgs.gov/wri/1997/4261/report.pdf.]

Standard Methods for the Examination of Water and Wastewater, 2018, 5310 total organic carbon (TOC) (2017): Standard Methods for the Examination of Water and Wastewater web page, accessed October 2018 at https://smww.aphapublications.org/doi/full/10.2105/SMWW.2882.104.

Struzeski, T.M., DeGiacomo, W.J., and Zayhowski, E.J., 1996, Methods of analysis by the U.S. Geological Survey National Water Quality Laboratory-Determination of dissolved aluminum and boron in water by inductively coupled plasma-atomic emission spectrometry: U.S. Geological Survey Open-File Report 96-149, 17 p. [Also available at https://pubs.er.usgs.gov/publication/ofr96149.]

Tucci, P., and McKay, R.M., 2006, Hydrogeology and simulation of ground-water flow in the Silurian-Devonian aquifer system, Johnson County, Iowa: U.S. Geological Survey Scientific Investigations Report 2005-5266, 73 p.

Turco, M.J., and Buchmiller, R.C., 2004, Simulation of ground-water flow in the Cedar River alluvial aquifer flow system, Cedar Rapids, Iowa: U.S. Geological Survey Scientific Investigations Report 2004-5130, 39 p. [Also available at https://doi.org/10.3133/sir20045130.] 
University of Iowa, 2013, Iowa Stratigraphic Column: University of Iowa, IIHR - Hydroscience \& Engineering, accessed October 29, 2018, at https:/www.iihr.uiowa.edu/ igs/files/2014/04/Text-stratographic-coloumn-of-Iowa.pdf.

U.S. Census Bureau, 2018, QuickFacts, Cedar Rapids city, Iowa: U.S. Census Bureau web page, accessed January 2018 at https://www.census.gov/quickfacts/fact/table/cedarrapidscityiowa/PST045216.

U.S. Environmental Protection Agency, 2010, Cedar River watershed total maximum daily load for indicator bacteria, Escherichia coli (E. coli): U.S. Environmental Protection Agency, 463 p.

U.S. Geological Survey, variously dated, National field manual for the collection of water-quality data: U.S. Geological Survey Techniques of Water-Resources Investigations, book 9, chaps. A1-A9, accessed February 2018 at https://pubs. water.usgs.gov/twri9A.
U.S. Geological Survey, 2017, Pesticide National Synthesis Project: U.S. Geological Survey web page, accessed February 2018 at https://water.usgs.gov/nawqa/pnsp/.

U.S. Geological Survey, 2018, USGS water data for the Nation: U.S. Geological Survey National Water Information System database, accessed February 2018 at https://doi. org/10.5066/F7P55KJN.

Wahl, K.D., and Bunker, B.J., 1986, Hydrology of carbonate aquifers in southwestern Linn County and adjacent parts of Benton, Iowa, and Johnson Counties, Iowa: Iowa Geological Survey Water Supply Bulletin no. 15, 56 p.

Wershaw, R.L., Fishman, M.J., Grabbe, R.R., and Lowe, L.E., eds., 1987, Methods for the determination of organic substances in water and fluvial sediments: U.S. Geological Survey Techniques of Water-Resources Investigations, book 5, chap. A3, 80 p. 
Tables 9-19 


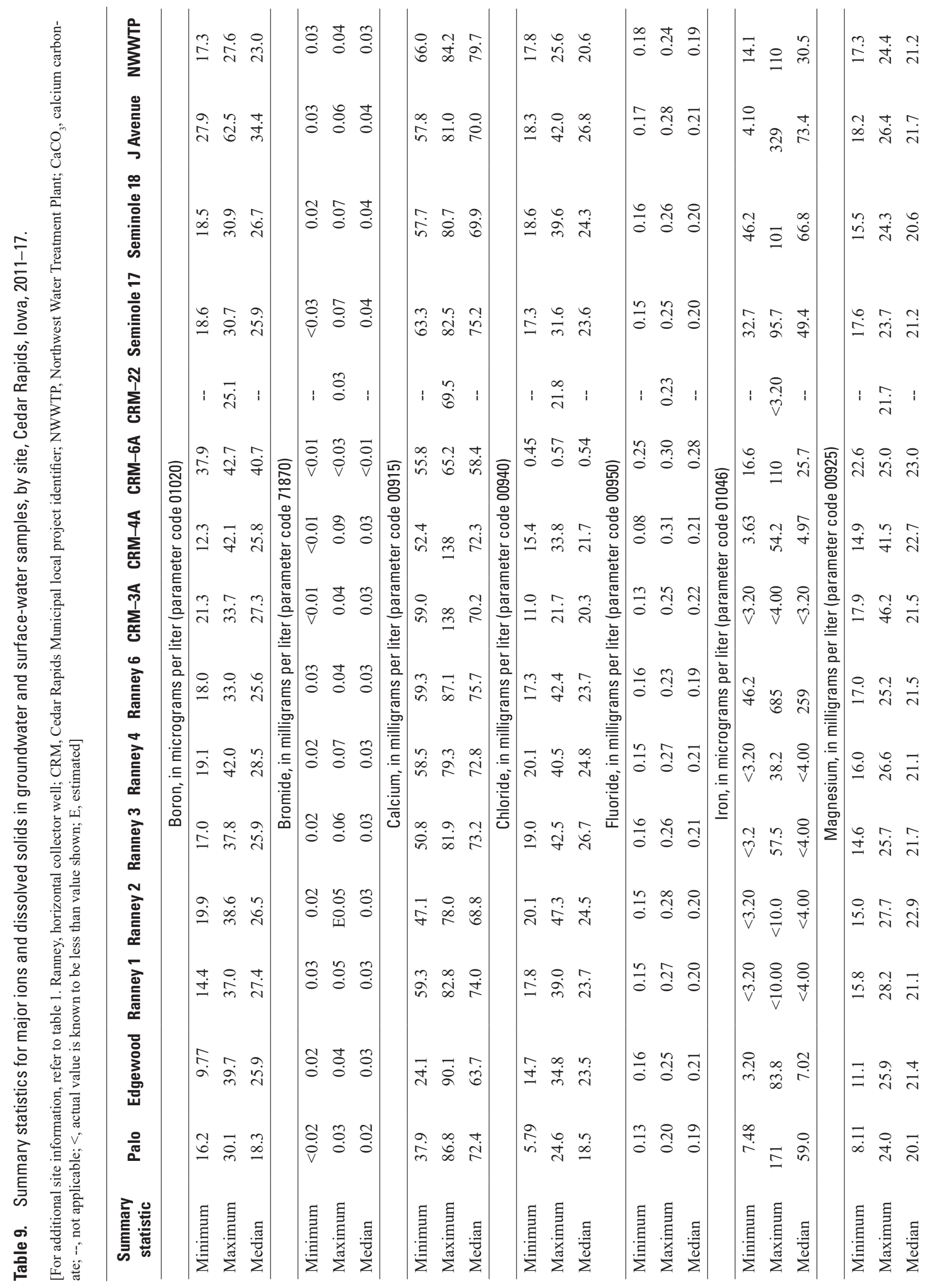




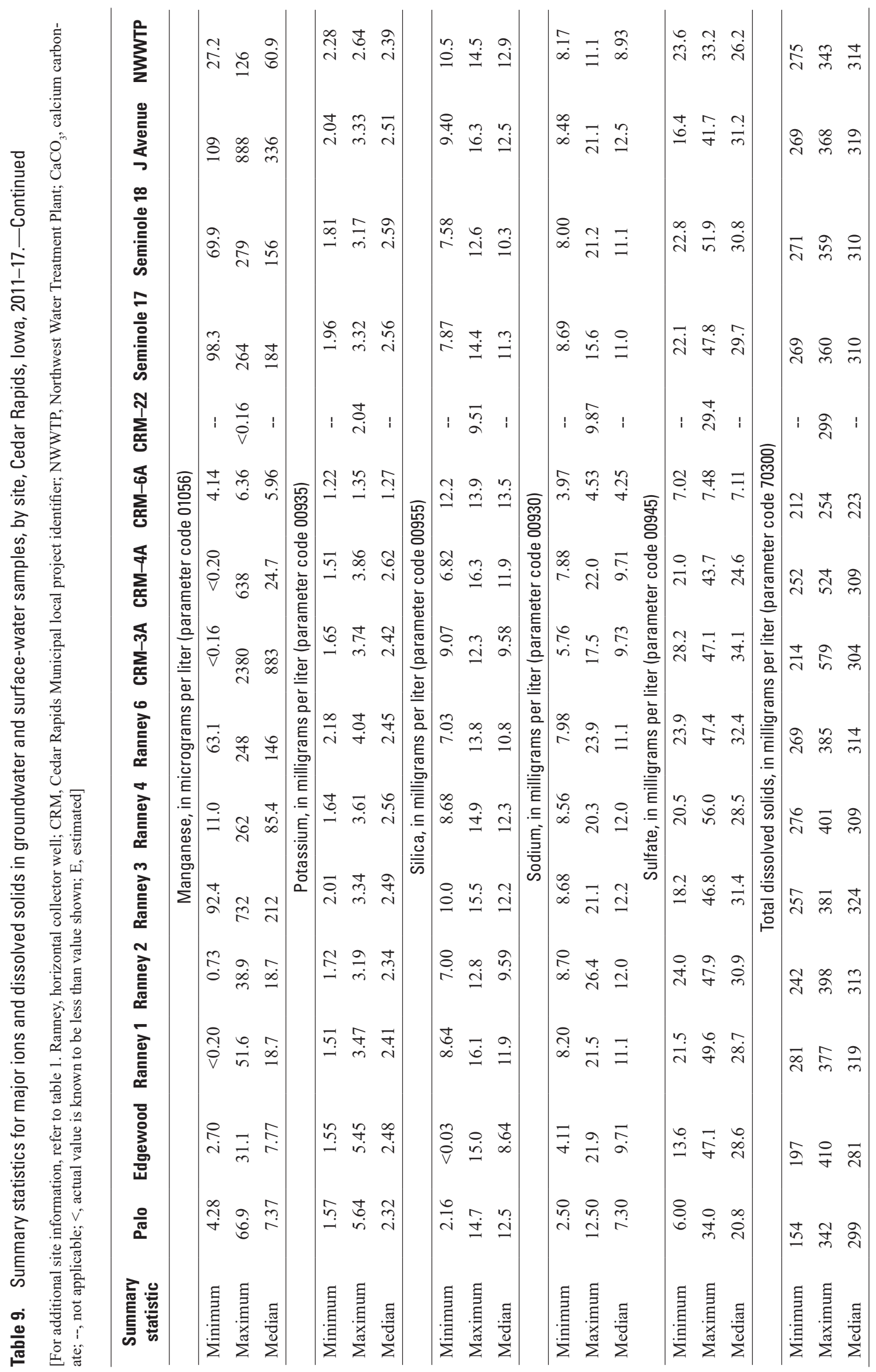




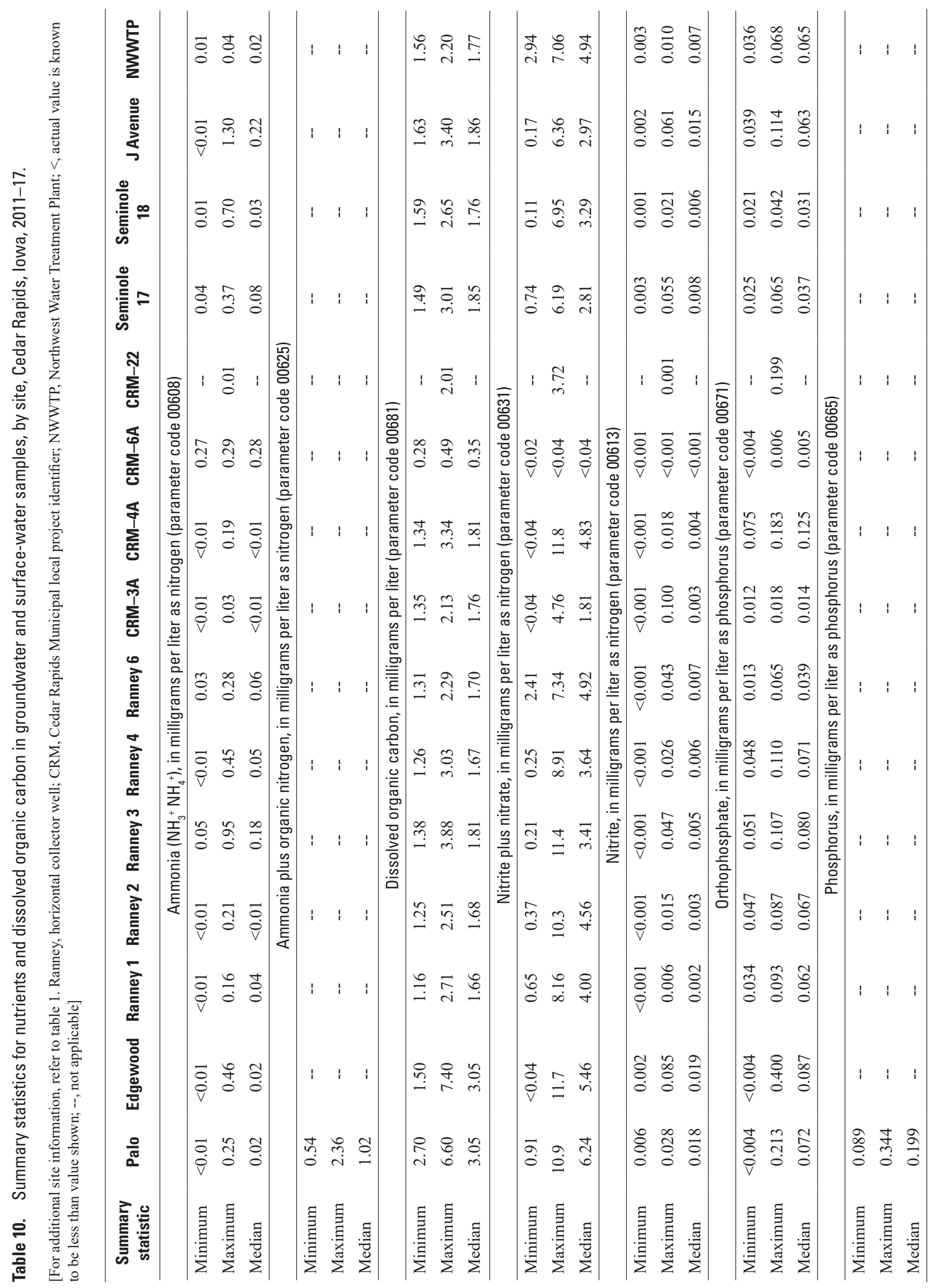


Table 11. Summary statistics for nutrients, dissolved organic carbon, and physical characteristics by treatment plant and the wells valved to them, Cedar Rapids, lowa, 2011-17.

[For additional site information, refer to table 1. Ranney, horizontal collector well; NWWTP, Northwest Water Treatment Plant; <, actual value known to be less than value shown]

\begin{tabular}{|c|c|c|c|c|c|c|c|c|c|}
\hline $\begin{array}{c}\text { Summary } \\
\text { statistic }\end{array}$ & Ranney 1 & Ranney 2 & Ranney 6 & $\begin{array}{c}\text { Seminole } \\
17\end{array}$ & $\begin{array}{c}\text { Seminole } \\
18\end{array}$ & NWWTP & Ranney 3 & Ranney 4 & J Avenue \\
\hline \multicolumn{10}{|c|}{ Ammonia $\left(\mathrm{NH}_{3}{ }^{+} \mathrm{NH}_{4}^{+}\right)$, in milligrams per liter as nitrogen (parameter code 00608) } \\
\hline Minimum & $<0.01$ & $<0.01$ & 0.03 & 0.04 & 0.01 & 0.01 & 0.05 & $<0.01$ & $<0.01$ \\
\hline Maximum & 0.16 & 0.21 & 0.28 & 0.37 & 0.70 & 0.04 & 0.95 & 0.45 & 1.30 \\
\hline Median & 0.04 & $<0.01$ & 0.06 & 0.08 & 0.03 & 0.02 & 0.18 & 0.05 & 0.22 \\
\hline \multicolumn{10}{|c|}{ Dissolved organic carbon, in milligrams per liter (parameter code 00681) } \\
\hline Minimum & 1.16 & 1.25 & 1.31 & 1.49 & 1.59 & 1.56 & 1.38 & 1.26 & 1.63 \\
\hline Maximum & 2.71 & 2.51 & 2.29 & 3.01 & 2.65 & 2.20 & 3.88 & 3.03 & 3.40 \\
\hline Median & 1.66 & 1.68 & 1.70 & 1.85 & 1.76 & 1.77 & 1.81 & 1.67 & 1.86 \\
\hline \multicolumn{10}{|c|}{ Dissolved oxygen, in milligrams per liter (parameter code 00300) } \\
\hline \multicolumn{10}{|c|}{ Nitrite plus nitrate, in milligrams per liter as nitrogen(parameter code 00631) } \\
\hline Minimum & 0.65 & 0.37 & 2.41 & 0.74 & 0.11 & 2.94 & 0.21 & 0.25 & 0.17 \\
\hline Maximum & 8.16 & 10.3 & 7.34 & 6.19 & 6.95 & 7.06 & 11.4 & 8.91 & 6.36 \\
\hline Median & 4.00 & 4.56 & 4.92 & 2.81 & 3.29 & 4.94 & 3.41 & 3.64 & 2.97 \\
\hline \multicolumn{10}{|c|}{ Nitrite, in milligrams per liter as nitrogen (parameter code 00613) } \\
\hline Minimum & $<0.001$ & $<0.001$ & $<0.001$ & 0.003 & 0.001 & 0.003 & $<0.001$ & $<0.001$ & 0.002 \\
\hline Maximum & 0.006 & 0.015 & 0.043 & 0.055 & 0.021 & 0.010 & 0.047 & 0.026 & 0.061 \\
\hline Median & 0.002 & 0.003 & 0.007 & 0.008 & 0.006 & 0.007 & 0.005 & 0.006 & 0.015 \\
\hline \multicolumn{10}{|c|}{ Orthophosphate, in milligrams per liter as phosphorus (parameter code 00671) } \\
\hline Maximum & 7.4 & 7.7 & 7.5 & 7.4 & 7.5 & 7.8 & 7.6 & 7.6 & 7.5 \\
\hline Median & 7.3 & 7.4 & 7.3 & 7.2 & 7.3 & 7.5 & 7.3 & 7.2 & 7.2 \\
\hline \multicolumn{10}{|c|}{ Specific conductance, in microsiemens per centimeter at 25 degrees Celsius (parameter code 00095) } \\
\hline Minimum & 466 & 413 & 471 & 488 & 452 & 484 & 433 & 459 & 489 \\
\hline Maximum & 659 & 688 & 674 & 602 & 616 & 597 & 647 & 709 & 638 \\
\hline Median & 551 & 552 & 548 & 545 & 524 & 555 & 553 & 548 & 554 \\
\hline \multicolumn{10}{|c|}{ Water temperature, in degrees Celsius (parameter code 00010) } \\
\hline Minimum & 3.8 & 2.8 & 4.8 & 3.8 & 4.5 & 6.6 & 5.1 & 4.4 & 5.3 \\
\hline Maximum & 21.6 & 24.1 & 20.7 & 20.2 & 20.1 & 20.8 & 23.2 & 22.8 & 21.5 \\
\hline Median & 14.5 & 15.1 & 14.6 & 14 & 14.2 & 14.8 & 15.2 & 14.9 & 14.1 \\
\hline
\end{tabular}


Table 12. Summary statistics for physical characteristics, major ions, and dissolved solids by treatment plant and the wells valved to them, Cedar Rapids, lowa, 2011-17.

[For additional site information, refer to table 1. Ranney, horizontal collector well; NWWTP, Northwest Water Treatment Plant; $\mathrm{CaCO}_{3}$, calcium carbonate; $<$, actual value is known to be less than value shown]

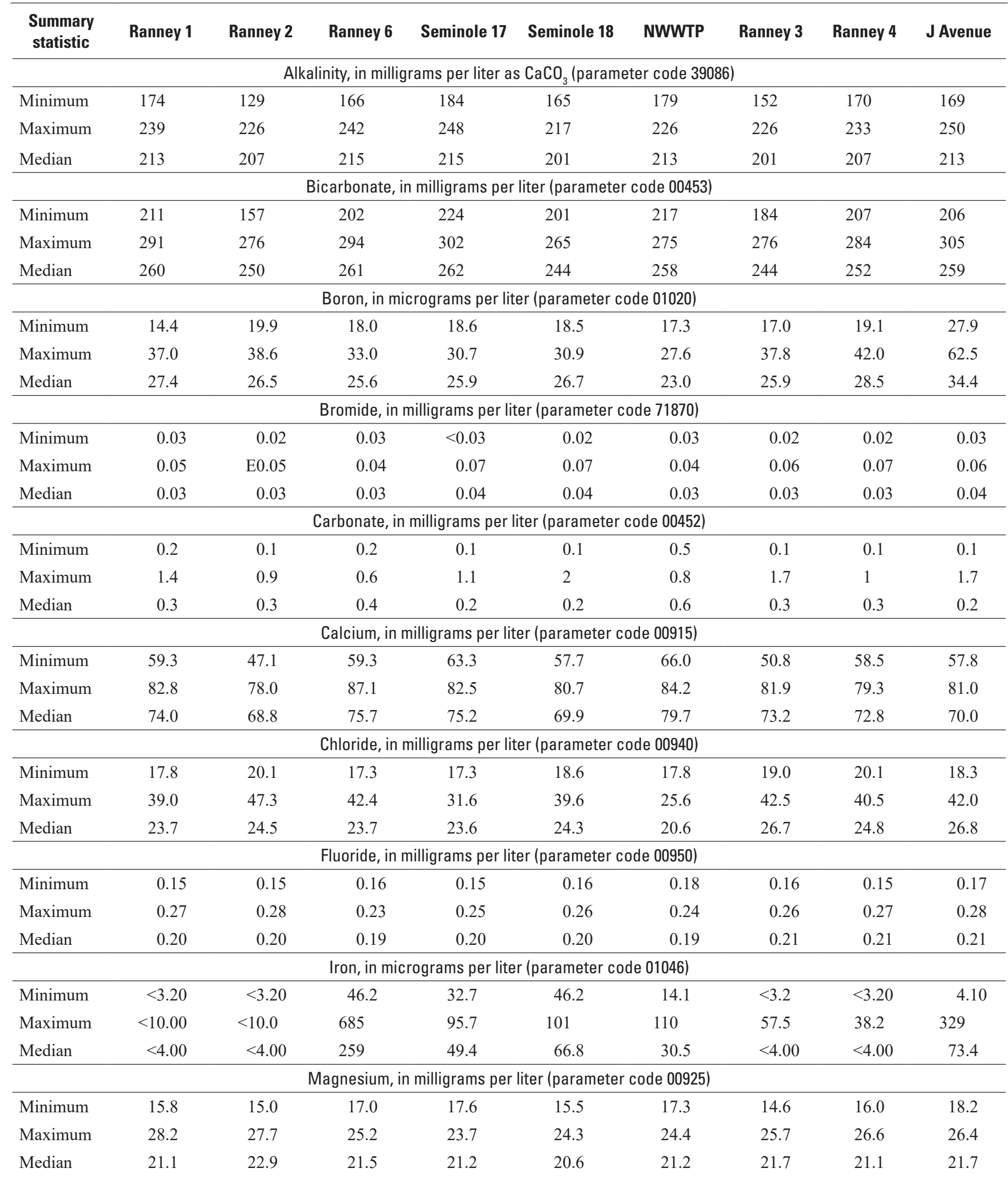


Table 12. Summary statistics for physical characteristics, major ions, and dissolved solids by treatment plant and the wells valved to them, Cedar Rapids, lowa, 2011-17.-Continued

[For additional site information, refer to table 1. Ranney, horizontal collector well; NWWTP, Northwest Water Treatment Plant; $\mathrm{CaCO}_{3}$, calcium carbonate; $<$, actual value is known to be less than value shown]

\begin{tabular}{|c|c|c|c|c|c|c|c|c|c|}
\hline $\begin{array}{l}\text { Summary } \\
\text { statistic }\end{array}$ & Ranney 1 & Ranney 2 & Ranney 6 & Seminole 17 & Seminole 18 & NWWTP & Ranney 3 & Ranney 4 & J Avenue \\
\hline \multicolumn{10}{|c|}{ Manganese, in micrograms per liter (parameter code 01056) } \\
\hline Maximum & 51.6 & 38.9 & 248 & 264 & 279 & 126 & 732 & 262 & 888 \\
\hline Median & 18.7 & 18.7 & 146 & 184 & 156 & 60.9 & 212 & 85.4 & 336 \\
\hline Minimum & 1.51 & 1.72 & 2.18 & 1.96 & 1.81 & 2.28 & 2.01 & 1.64 & 2.04 \\
\hline Maximum & 3.47 & 3.19 & 4.04 & 3.32 & 3.17 & 2.64 & 3.34 & 3.61 & 3.33 \\
\hline Median & 2.41 & 2.34 & 2.45 & 2.56 & 2.59 & 2.39 & 2.49 & 2.56 & 2.51 \\
\hline \multicolumn{10}{|c|}{ Silica, in milligrams per liter (parameter code 00955) } \\
\hline Minimum & 8.64 & 7.00 & 7.03 & 7.87 & 7.58 & 10.5 & 10.0 & 8.68 & 9.40 \\
\hline \multicolumn{10}{|c|}{ Sodium, in milligrams per liter (parameter code 00930) } \\
\hline Minimum & 8.20 & 8.70 & 7.98 & 8.69 & 8.00 & 8.17 & 8.68 & 8.56 & 8.48 \\
\hline Maximum & 21.5 & 26.4 & 23.9 & 15.6 & 21.2 & 11.1 & 21.1 & 20.3 & 21.1 \\
\hline Median & 11.1 & 12.0 & 11.1 & 11.0 & 11.1 & 8.93 & 12.2 & 12.0 & 12.5 \\
\hline \multicolumn{10}{|c|}{ Sulfate, in milligrams per liter (parameter code 00945) } \\
\hline Minimum & 21.5 & 24.0 & 23.9 & 22.1 & 22.8 & 23.6 & 18.2 & 20.5 & 16.4 \\
\hline Maximum & 49.6 & 47.9 & 47.4 & 47.8 & 51.9 & 33.2 & 46.8 & 56.0 & 41.7 \\
\hline Median & 28.7 & 30.9 & 32.4 & 29.7 & 30.8 & 26.2 & 31.4 & 28.5 & 31.2 \\
\hline \multicolumn{10}{|c|}{ Total dissolved solids, in milligrams per liter (parameter code 70300) } \\
\hline
\end{tabular}


Table 13. Description of parent compound pesticides in water-quality samples, Cedar Rapids, lowa, 2011-17.

[This report contains Chemical Abstracts Service Registry Numbers ${ }^{\circledR}$, which are a Registered Trademark of the American Chemical Society. The Chemical Abstracts Service recommends the verification of the Registry Numbers through Chemical Abstracts Service Client Services ${ }^{\text {SM }}$. CASRN, Chemical Abstracts Service Registry Number $\left.{ }^{\circledR}\right]$

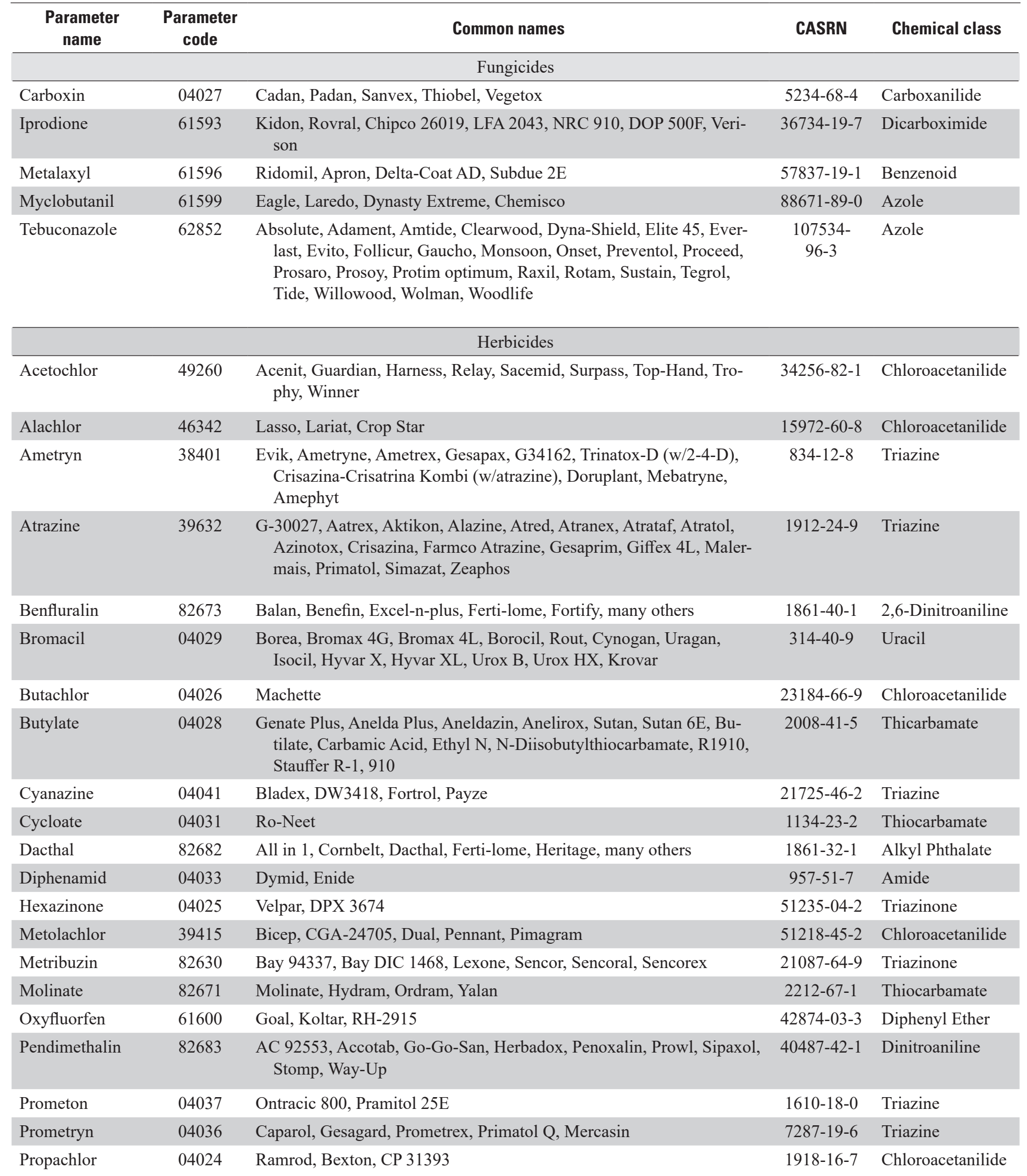


Table 13. Description of parent compound pesticides in water-quality samples, Cedar Rapids, lowa, 2011-17._-Continued

[This report contains Chemical Abstracts Service Registry Numbers ${ }^{\circledR}$, which are a Registered Trademark of the American Chemical Society. The Chemical Abstracts Service recommends the verification of the Registry Numbers through Chemical Abstracts Service Client Services ${ }^{\mathrm{SM}}$. CASRN, Chemical Abstracts Service Registry Number $\left.{ }^{\circledR}\right]$

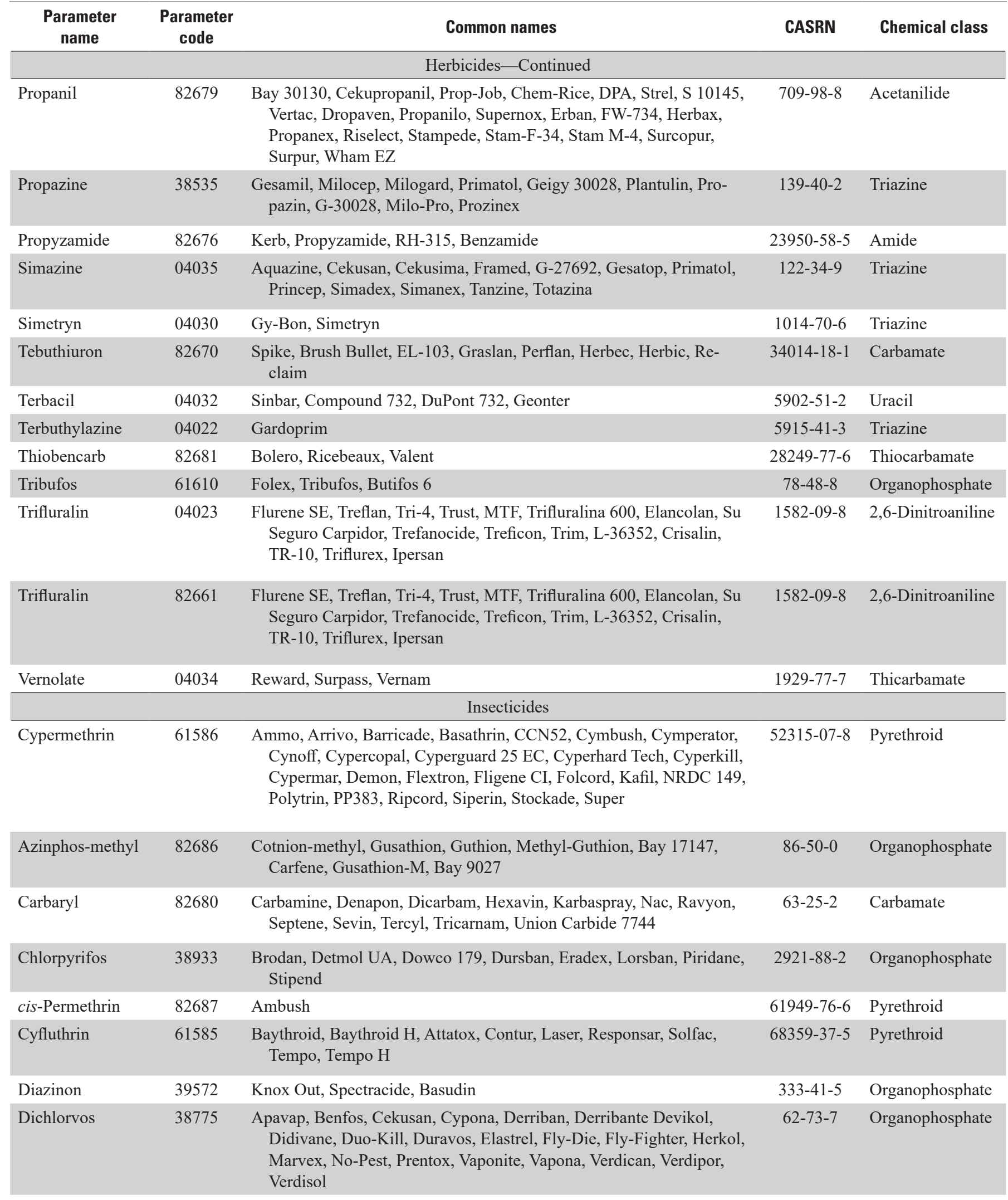


Table 13. Description of parent compound pesticides in water-quality samples, Cedar Rapids, lowa, 2011-17.—Continued

[This report contains Chemical Abstracts Service Registry Numbers ${ }^{\circledR}$, which are a Registered Trademark of the American Chemical Society. The Chemical Abstracts Service recommends the verification of the Registry Numbers through Chemical Abstracts Service Client Services ${ }^{\text {SM }}$. CASRN, Chemical Abstracts Service Registry Number $\left.{ }^{\circledR}\right]$

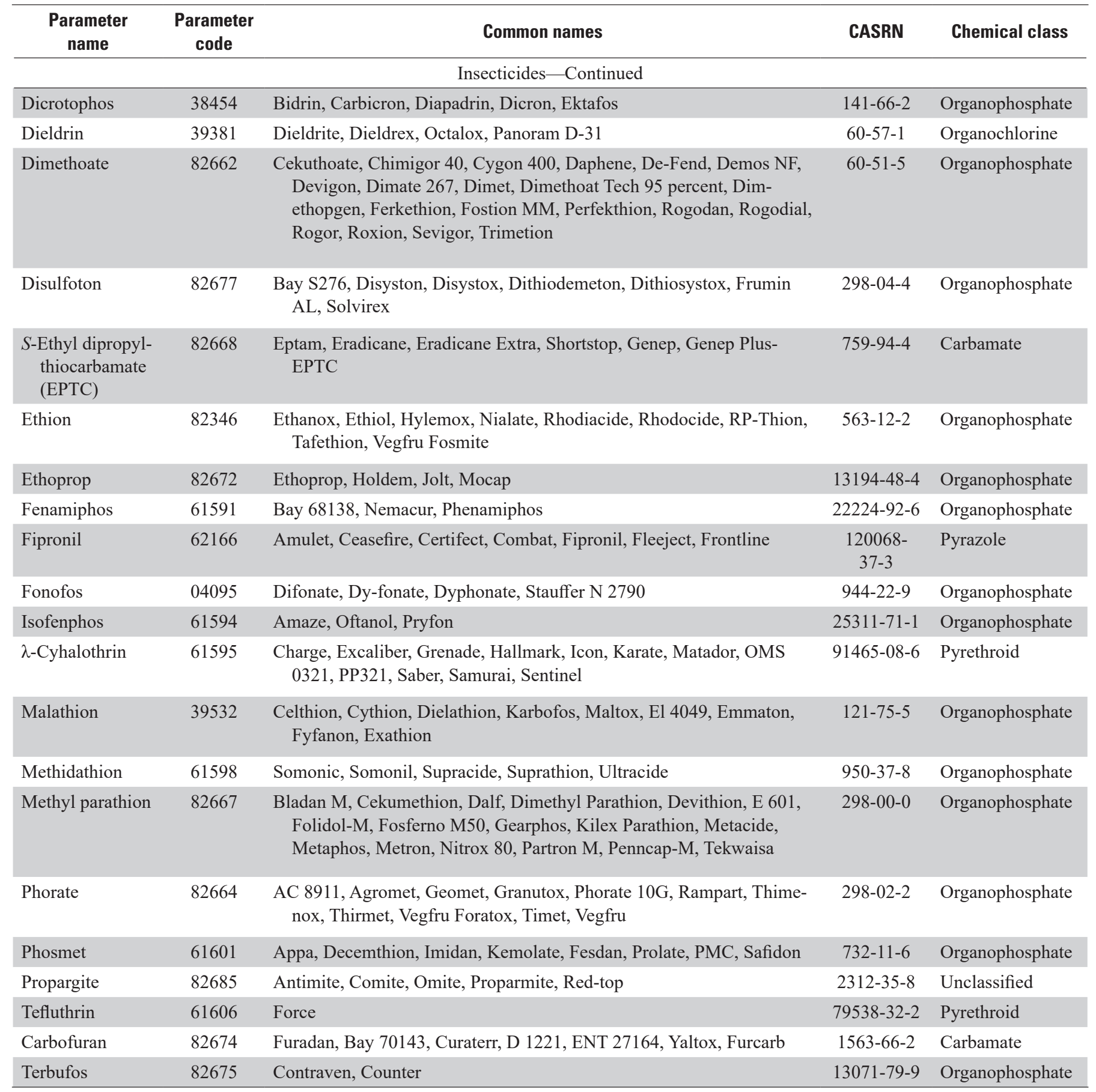


Table 14. Description of pesticide degradates and intermediates in water-quality samples, Cedar Rapids, lowa, 2011-17.

[This report contains Chemical Abstracts Service Registry Numbers ${ }^{\circledR}$, which are a registered trademark of the American Chemical Society. The Chemical Abstracts Service recommends the verification of the Registry Numbers through Chemical Abstracts Service Client Services ${ }^{\mathrm{SM}}$. CASRN, Chemical Abstracts

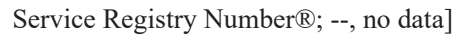

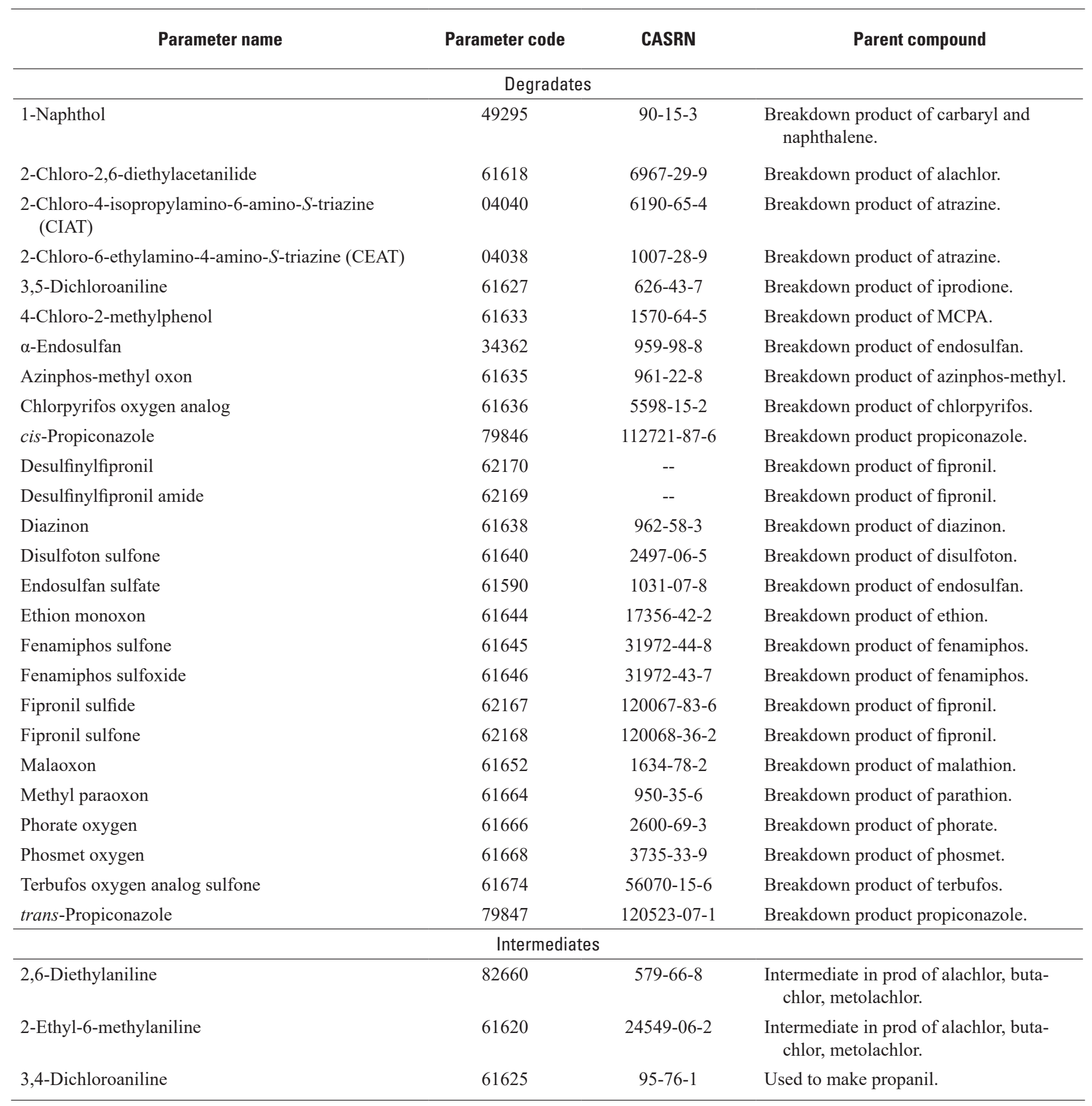


Table 15. Pesticides sampled for but not detected in water-quality samples, Cedar Rapids, lowa, 2011-17.

\begin{tabular}{|c|c|c|c|}
\hline Parameter name & Parameter code & Parameter name & Parameter code \\
\hline 1-Naphthol & 49295 & Fipronil $^{1}$ & 62166 \\
\hline 2,6-Diethylaniline & 82660 & Fipronil sulfide ${ }^{1}$ & 62167 \\
\hline 2-Chloro-2,6-diethylacetanilide & 61618 & Fipronil sulfone & 62168 \\
\hline 2-Ethyl-6-methylaniline & 61620 & Fonofos & 04095 \\
\hline 3,4-Dichloroaniline & 61625 & Hexazinone $^{1}$ & 04025 \\
\hline 3,5-Dichloroaniline & 61627 & Iprodione & 61593 \\
\hline 4-Chloro-2-methylphenol & 61633 & Isofenphos & 61594 \\
\hline Alachlor ${ }^{1}$ & 46342 & $\lambda$-Cyhalothrin & 61595 \\
\hline$\alpha$-Endosulfan & 34362 & Malaoxon & 61652 \\
\hline Ametryn & 38401 & Malathion & 39532 \\
\hline Azinphos-methyl & 82686 & Metalaxyl $^{1}$ & 61596 \\
\hline Azinphos-methyl oxygen analog & 61635 & Methidathion & 61598 \\
\hline Benfluralin & 82673 & Methyl parathion & 82667 \\
\hline Butachlor & 04026 & Molinate & 82671 \\
\hline Butylate & 04028 & Myclobutanil & 61599 \\
\hline Carbaryl & 82680 & Oxyfluorfen & 61600 \\
\hline Carbofuran & 82674 & Methyl paraoxon & 61664 \\
\hline Carboxin & 04027 & Pendimethalin & 82683 \\
\hline Chlorpyrifos & 38933 & Phorate & 82664 \\
\hline Chlorpyrifos oxygen analog & 61636 & Phorate oxygen analog & 61666 \\
\hline cis-Permethrin ${ }^{1}$ & 82687 & Phosmet & 61601 \\
\hline cis-Propiconazole ${ }^{1}$ & 79846 & Phosmet oxygen analog & 61668 \\
\hline Cyanazine & 04041 & Prometryn & 04036 \\
\hline Cycloate & 04031 & Propachlor & 04024 \\
\hline Cyfluthrin & 61585 & Propanil & 82679 \\
\hline Cypermethrin & 61586 & Propargite & 82685 \\
\hline Desulfinulfilpronil amide & 62169 & Propazine $^{1}$ & 38535 \\
\hline Desulfinylfipronil $^{1}$ & 62170 & Propyzamide & 82676 \\
\hline Diazinon & 39572 & $S$-Ethyl dipropylthiocarbamate (EPTC) & 82668 \\
\hline Diazoxon & 61638 & Simetryn & 04030 \\
\hline Dichlorvos & 38775 & Tebuthiuron & 82670 \\
\hline Dicrotophos & 38454 & Tefluthrin $^{1}$ & 61606 \\
\hline Dieldrin & 39381 & Terbacil & 04032 \\
\hline Dimethoate & 82662 & Terbufos & 82675 \\
\hline Diphenamid & 04033 & Terbufos oxygen analog sulfone & 61674 \\
\hline Disulfoton & 82677 & Terbuthylazine & 04022 \\
\hline Disulfoton sulfone & 61640 & Thiobencarb & 82681 \\
\hline Endosulfan sulfate & 61590 & trans-Propiconazole $^{1}$ & 79847 \\
\hline Ethion & 82346 & Tribufos & 61610 \\
\hline Ethion monoxon & 61644 & Trifluralin $^{1}$ & 82661 \\
\hline Ethoprop & 82672 & Trifluralin $^{1}$ & 04023 \\
\hline Fenamiphos & 61591 & Vernolate & 04034 \\
\hline Fenamiphos sulfone & 61645 & & \\
\hline Fenamiphos sulfoxide & 61646 & & \\
\hline
\end{tabular}

${ }^{1}$ Denotes detections less than laboratory reporting level. 


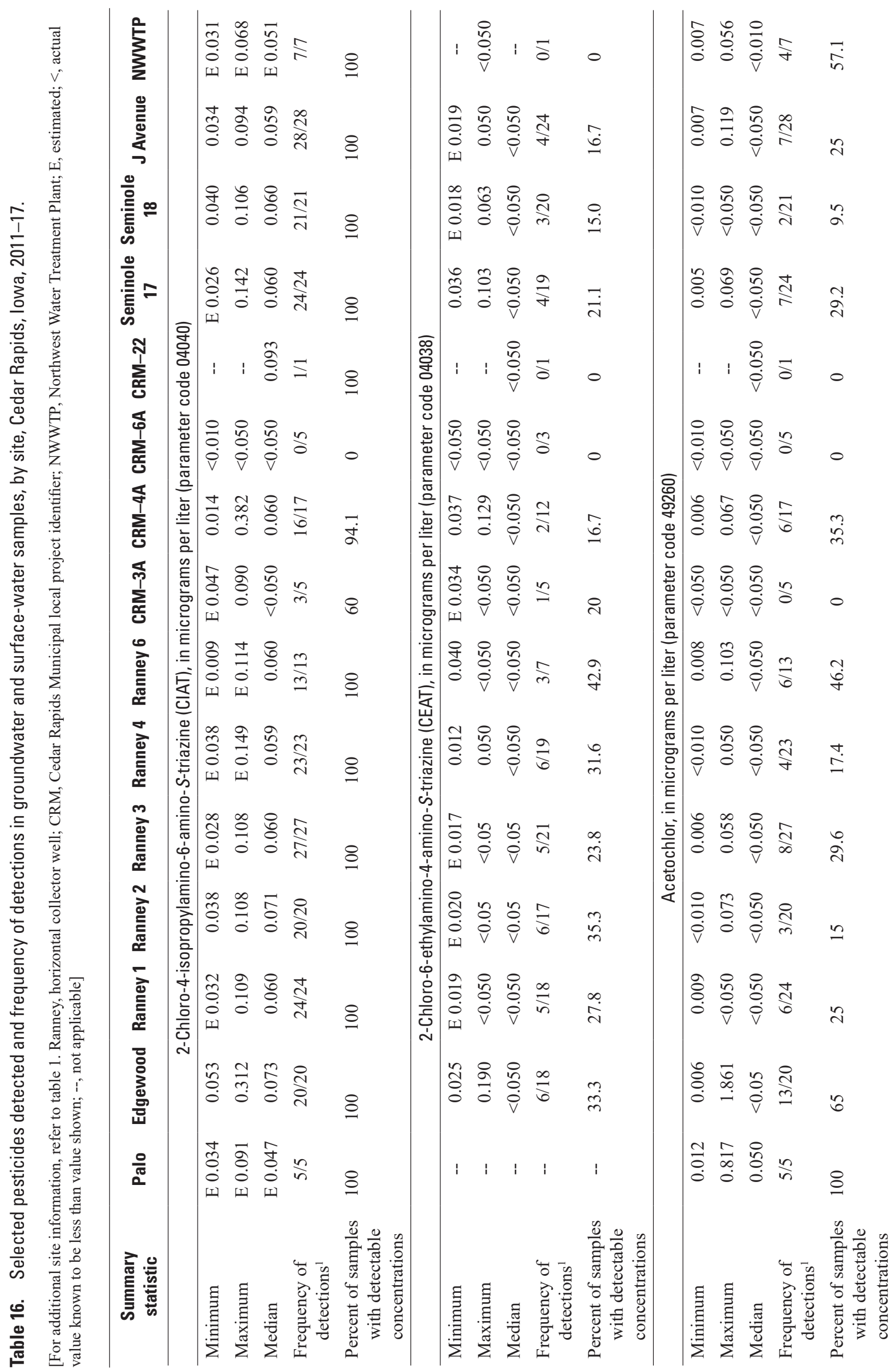




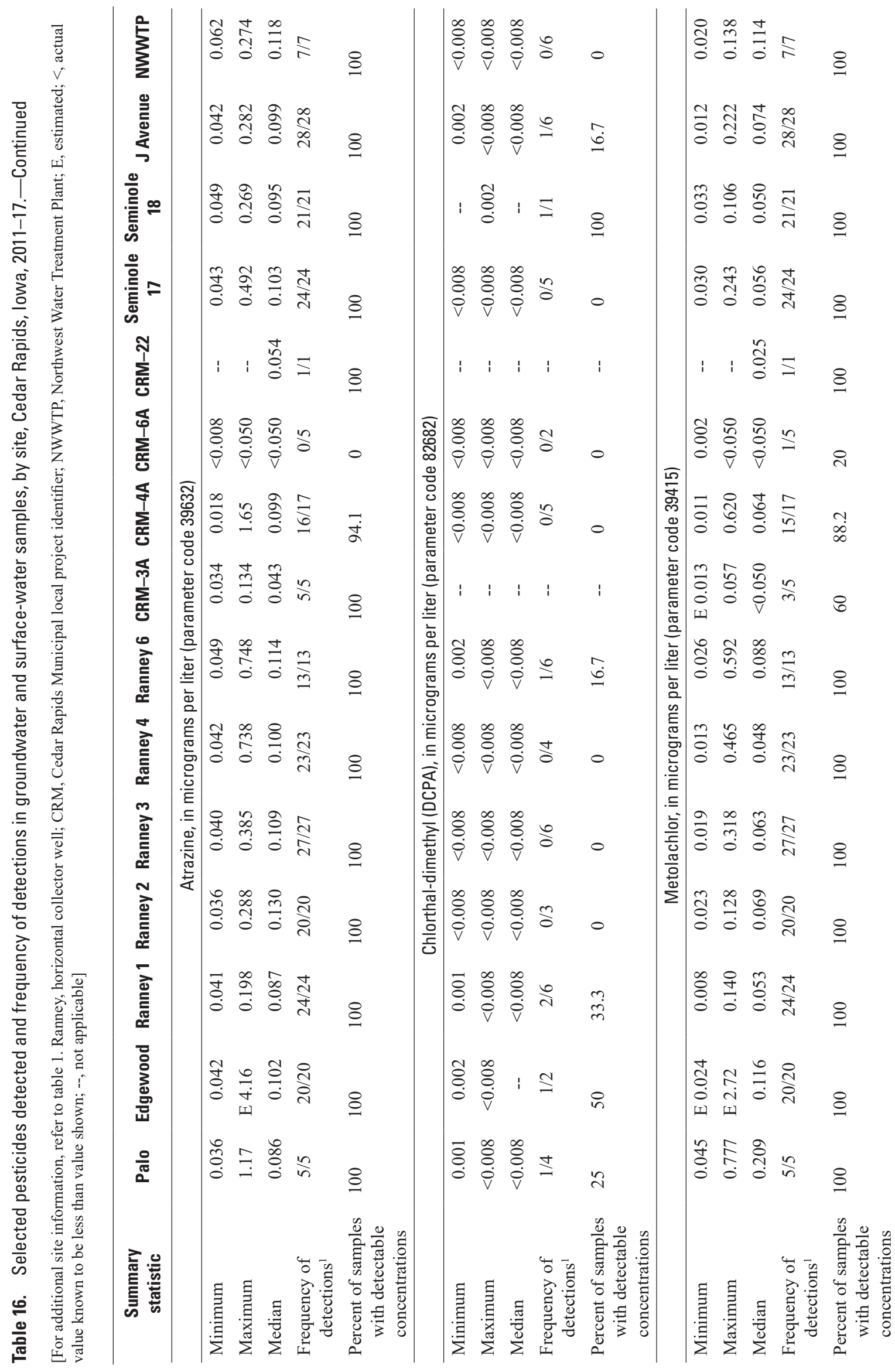




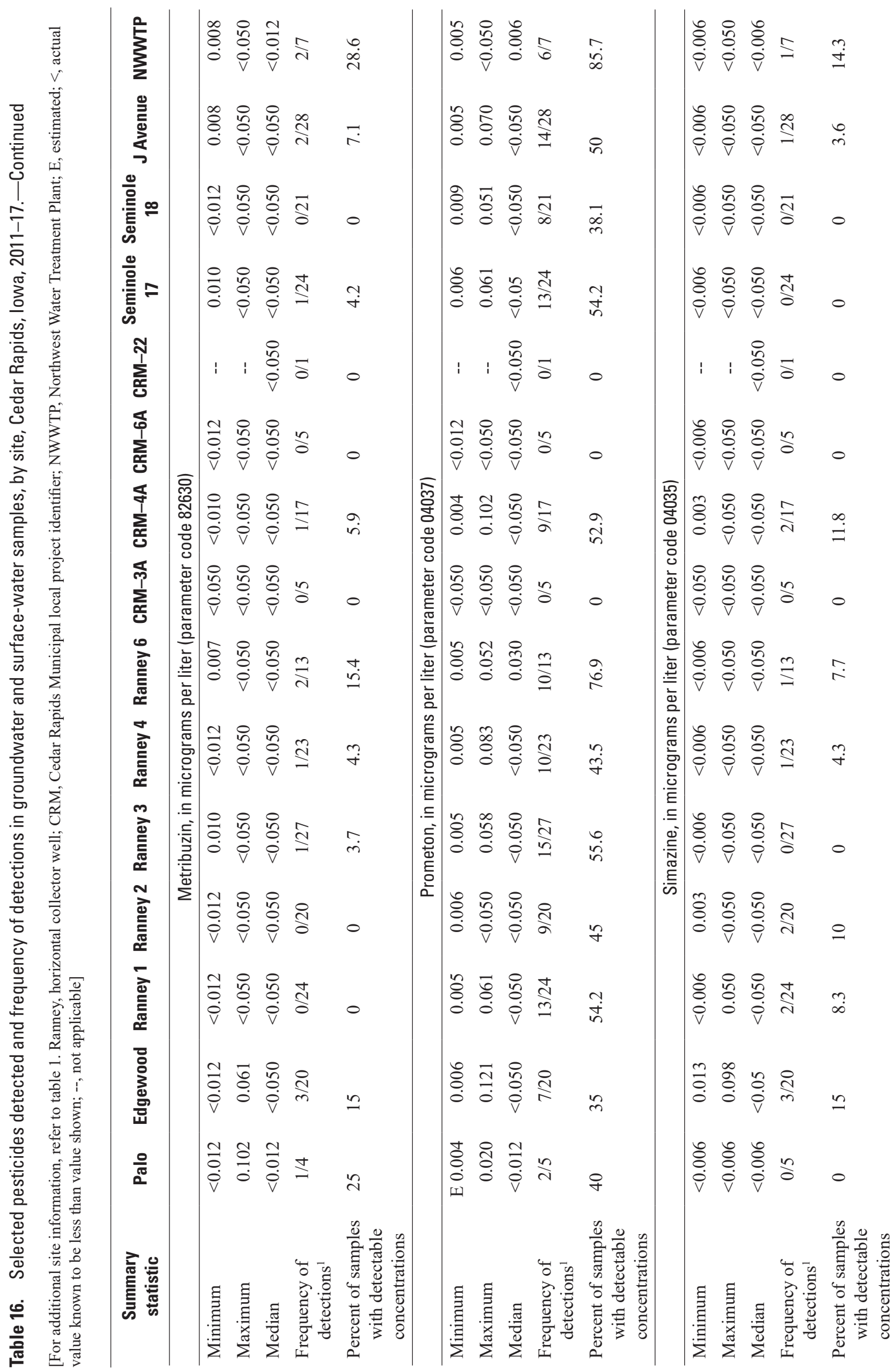




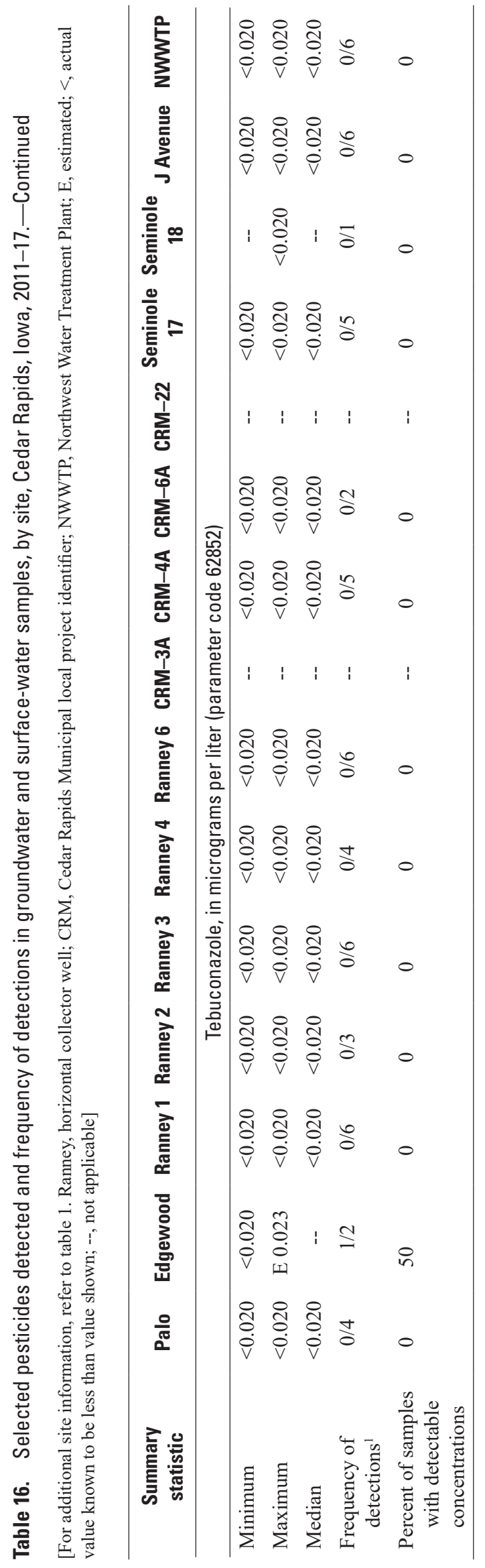




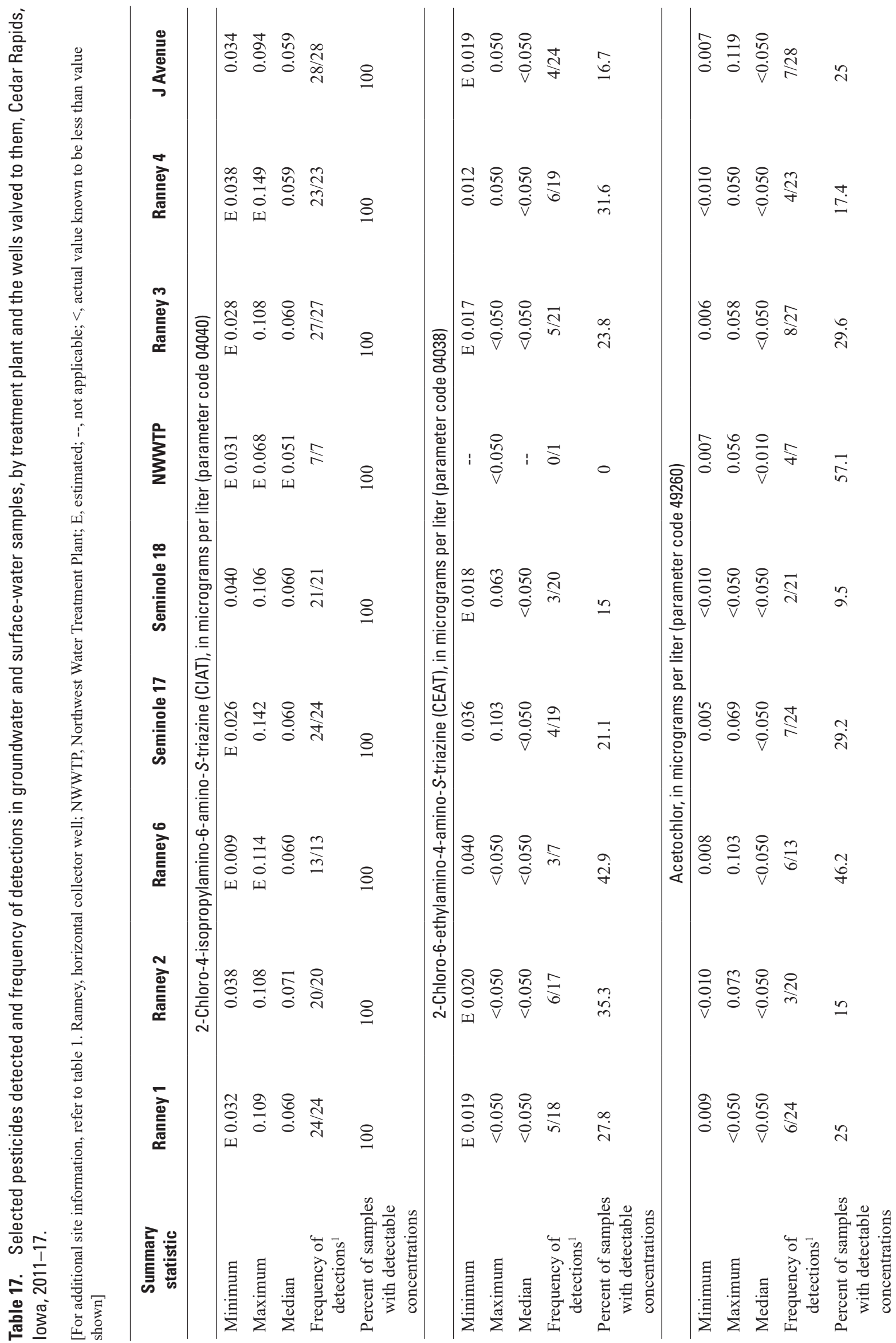




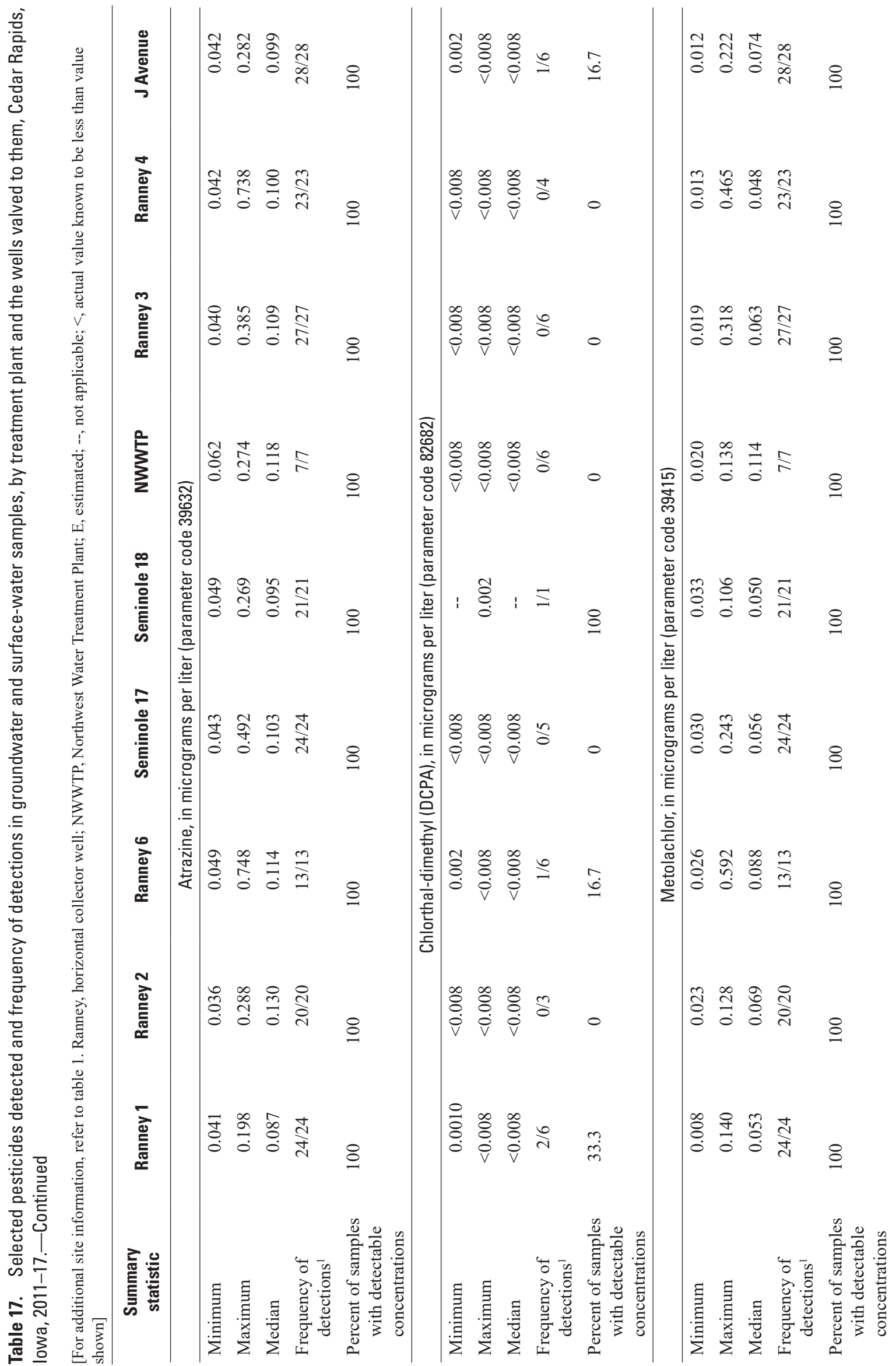




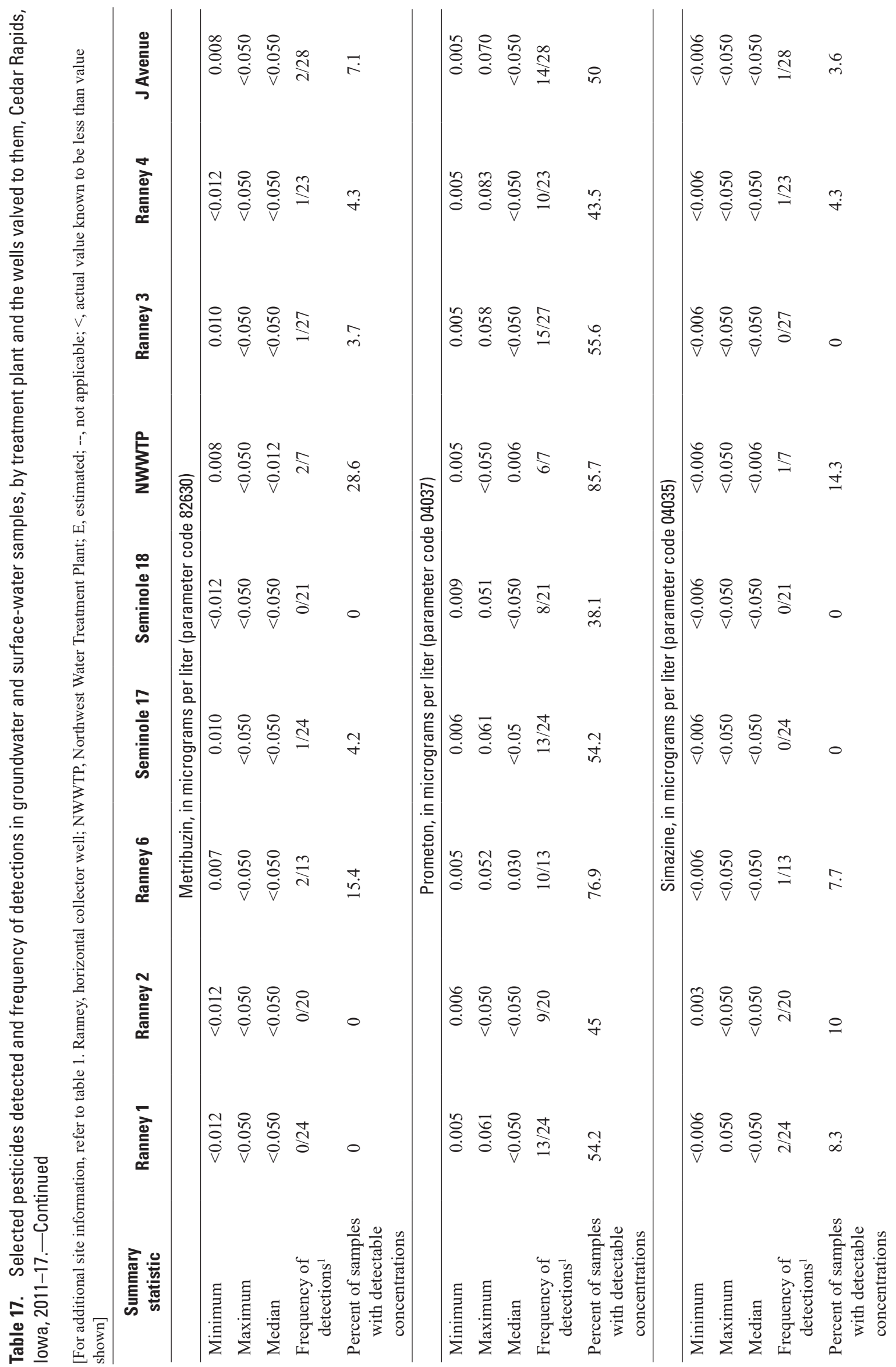




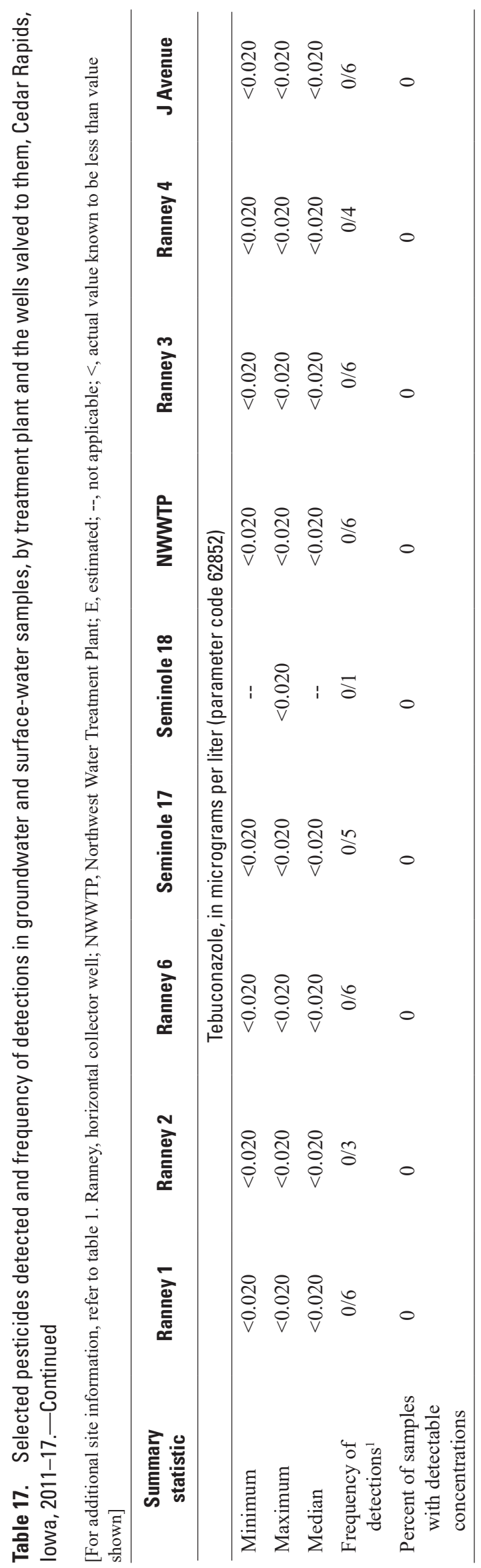


Table 18. Summary statistics for total coliform and Escherichia coli in groundwater and surface-water samples, by site, Cedar Rapids, lowa, 2011-17.

[For additional site information, refer to table 1. Ranney, horizontal collector well; CRM, Cedar Rapids Municipal local project identifier; NWWTP, Northwest Water Treatment Plant; MPN, most probable number; $\mathrm{mL}$, milliliter; <, actual value is known to be less than value shown;]

\begin{tabular}{|c|c|c|c|c|c|c|c|c|c|}
\hline $\begin{array}{l}\text { Summary } \\
\text { statistic }\end{array}$ & Palo & Edgewood & Ranney 4 & Ranney 6 & CRM-3A & CRM-4A & Seminole 17 & J Avenue & NWWTP \\
\hline \multicolumn{10}{|c|}{ Escherichia coli (MPN/100 mL; parameter code 50468) } \\
\hline Minimum & 27 & 2 & $<1$ & $<1$ & $<1$ & $<1$ & $<1$ & $<1$ & $<1$ \\
\hline Maximum & 387 & 20,300 & 28 & $<1$ & $<1$ & $<1$ & $<1$ & 3 & 1 \\
\hline Median & 100 & 23 & $<1$ & $<1$ & $<1$ & $<1$ & $<1$ & $<1$ & $<1$ \\
\hline \multicolumn{10}{|c|}{ Total coliforms (MPN/100 mL; parameter code 50569) } \\
\hline Minimum & 3,600 & 390 & $<1$ & $<1$ & $<1$ & $<1$ & $<1$ & $<1$ & $<1$ \\
\hline Maximum & 25,000 & 110,000 & 68 & 42 & 41 & 54 & 8 & 190 & 820 \\
\hline Median & 10,250 & 8,500 & $<1$ & $<1$ & $<1$ & $<1$ & $<1$ & $<1$ & 55 \\
\hline
\end{tabular}


Table 19. Results for quantitative polymerase chain reaction and quantitative reverse-transcription polymerase chain reaction viral pathogen samples, Cedar Rapids, lowa, 2008-17.

[E, result is estimated; $t$, result is greater than the limit of blank but less than the limit of detection; <, result is below the limit of detection; N/A, not applicable; b, result is extrapolated below the limit of quantification; Ranney, horizontal collector well; CRM, Cedar Rapids Municipal local project identifier; bold values are detections; molecular methods reported in copies per liter]

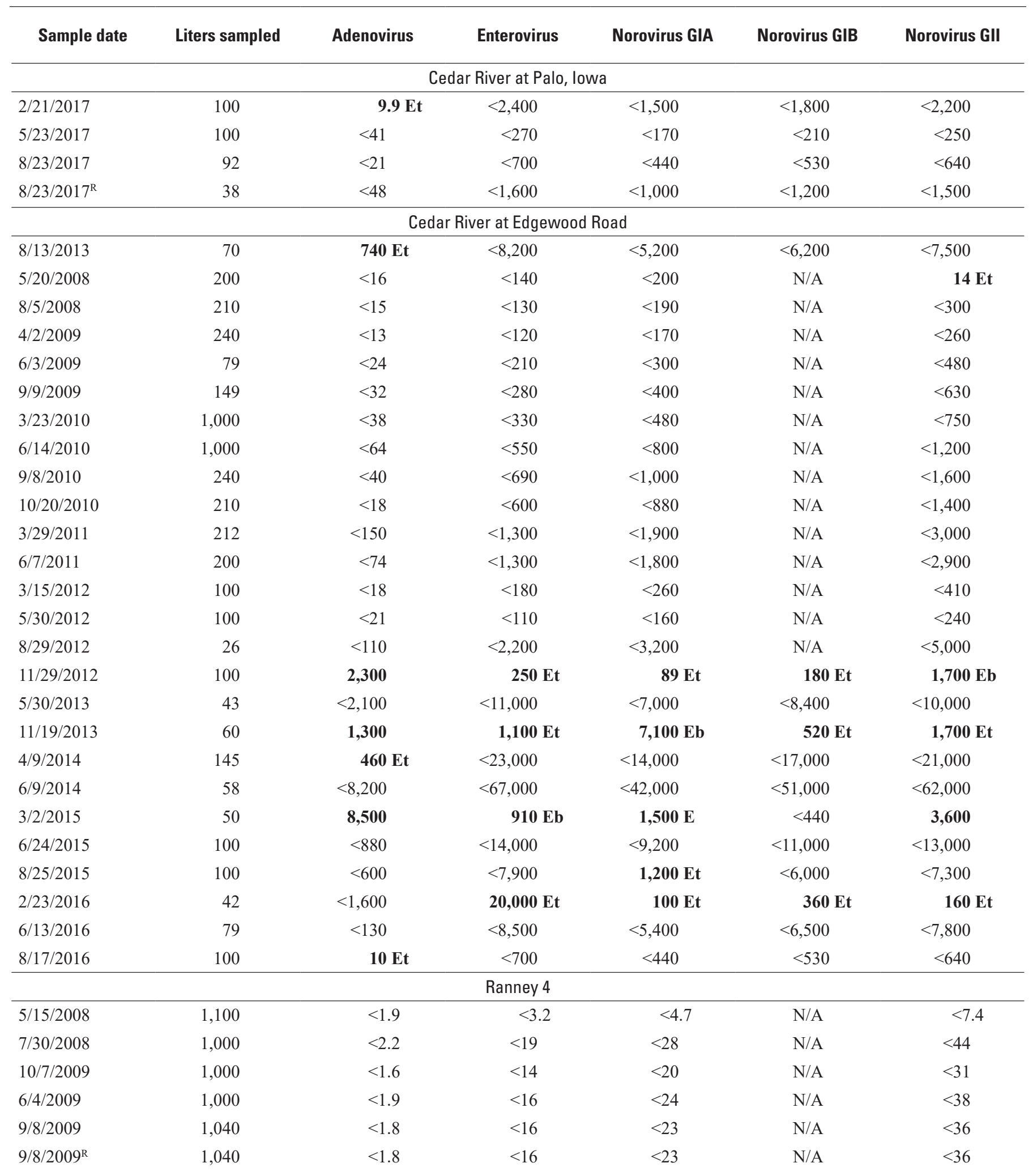


Table 19. Results for quantitative polymerase chain reaction and quantitative reverse-transcription polymerase chain reaction viral pathogen samples, Cedar Rapids, lowa, 2008-17.-Continued

[E, result is estimated; $t$, result is greater than the limit of blank but less than the limit of detection; <, result is below the limit of detection; N/A, not applicable; b, result is extrapolated below the limit of quantification; Ranney, horizontal collector well; CRM, Cedar Rapids Municipal local project identifier; bold values are detections; molecular methods reported in copies per liter]

\begin{tabular}{|c|c|c|c|c|c|c|}
\hline \multicolumn{7}{|c|}{ Ranney 4-Continued } \\
\hline $7 / 19 / 2010^{\mathrm{R}}$ & 1,020 & $<1.9$ & $<32$ & $<47$ & N/A & $<74$ \\
\hline $8 / 30 / 2010$ & 1,000 & $<1.6$ & $<5.5$ & $<8.0$ & $\mathrm{~N} / \mathrm{A}$ & $<12$ \\
\hline $3 / 15 / 2011$ & 1,000 & $<1.3$ & $<22$ & $<32$ & $\mathrm{~N} / \mathrm{A}$ & $<50$ \\
\hline $6 / 7 / 2011$ & 1,000 & $<0.32$ & $<1.1$ & $<1.6$ & N/A & $<2.5$ \\
\hline $1 / 21 / 2011$ & 1,000 & $<1.0$ & $<10$ & $<15$ & N/A & $<24$ \\
\hline $3 / 29 / 2012$ & 1,000 & $<0.99$ & $1.3 \mathrm{Et}$ & $<15$ & $\mathrm{~N} / \mathrm{A}$ & $<23$ \\
\hline $8 / 21 / 2012$ & 1,000 & $<0.86$ & $<8.9$ & $<13$ & $\mathrm{~N} / \mathrm{A}$ & $<20$ \\
\hline $12 / 10 / 2013$ & 1,000 & $<5.6$ & $<29$ & $<18$ & $<22$ & $<27$ \\
\hline $3 / 24 / 2014$ & 1,000 & $2.5 \mathrm{Et}$ & $52 \mathrm{Et}$ & $<75$ & $2.3 \mathrm{Et}$ & $<110$ \\
\hline $6 / 4 / 2014$ & 1,000 & $<3.7$ & $<120$ & $<77$ & $<93$ & $<110$ \\
\hline $9 / 22 / 2014$ & 1,000 & $3.4 \mathrm{Et}$ & $<50$ & $<32$ & $<38$ & $7.2 \mathrm{Et}$ \\
\hline $11 / 17 / 2014$ & 1,000 & $<4.8$ & $<31$ & $<20$ & $<24$ & $<29$ \\
\hline $2 / 24 / 2015$ & 1,000 & $3.3 \mathrm{Et}$ & $2.6 \mathrm{Et}$ & $<19$ & $<23$ & $<28$ \\
\hline $8 / 19 / 2015$ & 1,000 & $<6.0$ & $<39$ & $<25$ & $<30$ & $<36$ \\
\hline $4 / 13 / 2016$ & 1,003 & $<7.1$ & 3,100 Eb & $<1,500$ & $<1,800$ & $<2,100$ \\
\hline $3 / 12 / 2014$ & 1,000 & $2.6 \mathrm{Et}$ & $<38$ & $<24$ & $10 \mathrm{Et}$ & $5.6 \mathrm{Et}$ \\
\hline $5 / 28 / 2014$ & 1,000 & $<58$ & $<190$ & $<120$ & $<150$ & $<180$ \\
\hline $9 / 24 / 2014$ & 480 & 64 & $<98$ & $<62$ & $<74$ & $<90$ \\
\hline $12 / 17 / 2014$ & 1,000 & $3.8 \mathrm{Et}$ & $<33$ & $<21$ & $<26$ & $<31$ \\
\hline $3 / 3 / 2015$ & 1,000 & $<5.4$ & $42 \mathrm{Et}$ & $<110$ & $<140$ & $<160$ \\
\hline $8 / 26 / 2015$ & 1,000 & $<30$ & $<39$ & $<25$ & $<30$ & $<36$ \\
\hline 2/9/2016 & 1,000 & $<5.6$ & $520 \mathrm{Et}$ & $<580$ & $<700$ & $<840$ \\
\hline $6 / 28 / 2016$ & 1,000 & 0.18 Et & $<140$ & $<86$ & $<100$ & $<130$ \\
\hline $8 / 2 / 2016$ & 1,001 & $<4.3$ & $<140$ & $<89$ & $9.3 \mathrm{Et}$ & $4.0 \mathrm{Et}$ \\
\hline $10 / 25 / 2016$ & 1,000 & $<4.0$ & $<130$ & $<83$ & $5.0 \mathrm{Et}$ & $<120$ \\
\hline $3 / 8 / 2017$ & 1,000 & $<11$ & $<370$ & $<240$ & $<280$ & $<340$ \\
\hline $5 / 22 / 2017$ & 1,000 & $<5.0$ & $<160$ & $<100$ & $<130$ & $<150$ \\
\hline $8 / 15 / 2017$ & 1,000 & $<3.5$ & $<46$ & $<29$ & $<35$ & $<42$ \\
\hline
\end{tabular}


Table 19. Results for quantitative polymerase chain reaction and quantitative reverse-transcription polymerase chain reaction viral pathogen samples, Cedar Rapids, lowa, 2008-17.-Continued

[E, result is estimated; $t$, result is greater than the limit of blank but less than the limit of detection; <, result is below the limit of detection; N/A, not applicable; b, result is extrapolated below the limit of quantification; Ranney, horizontal collector well; CRM, Cedar Rapids Municipal local project identifier; bold values are detections; molecular methods reported in copies per liter]

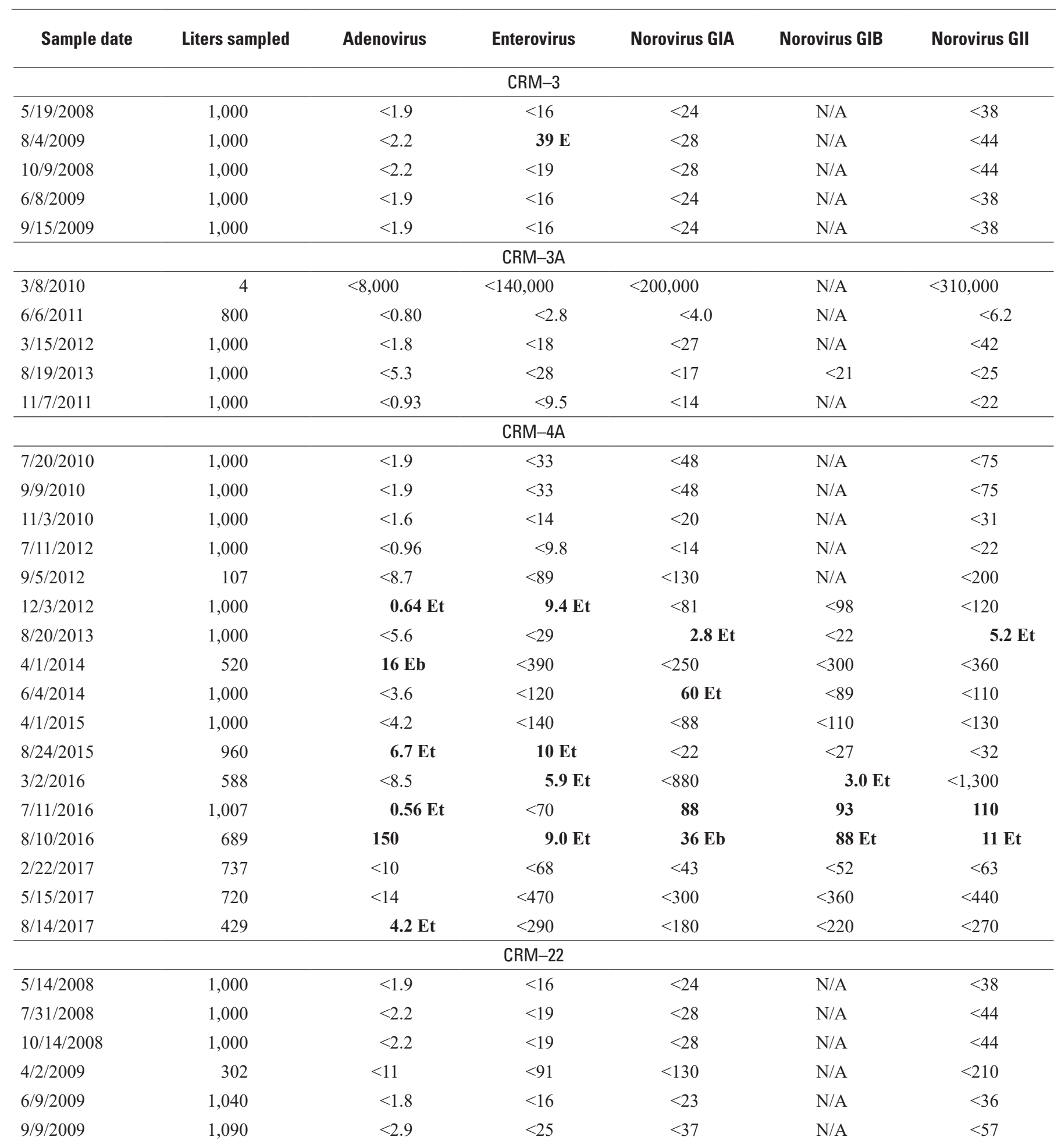


Table 19. Results for quantitative polymerase chain reaction and quantitative reverse-transcription polymerase chain reaction viral pathogen samples, Cedar Rapids, lowa, 2008-17.-Continued

[E, result is estimated; $t$, result is greater than the limit of blank but less than the limit of detection; <, result is below the limit of detection; N/A, not applicable; b, result is extrapolated below the limit of quantification; Ranney, horizontal collector well; CRM, Cedar Rapids Municipal local project identifier; bold values are detections; molecular methods reported in copies per liter]

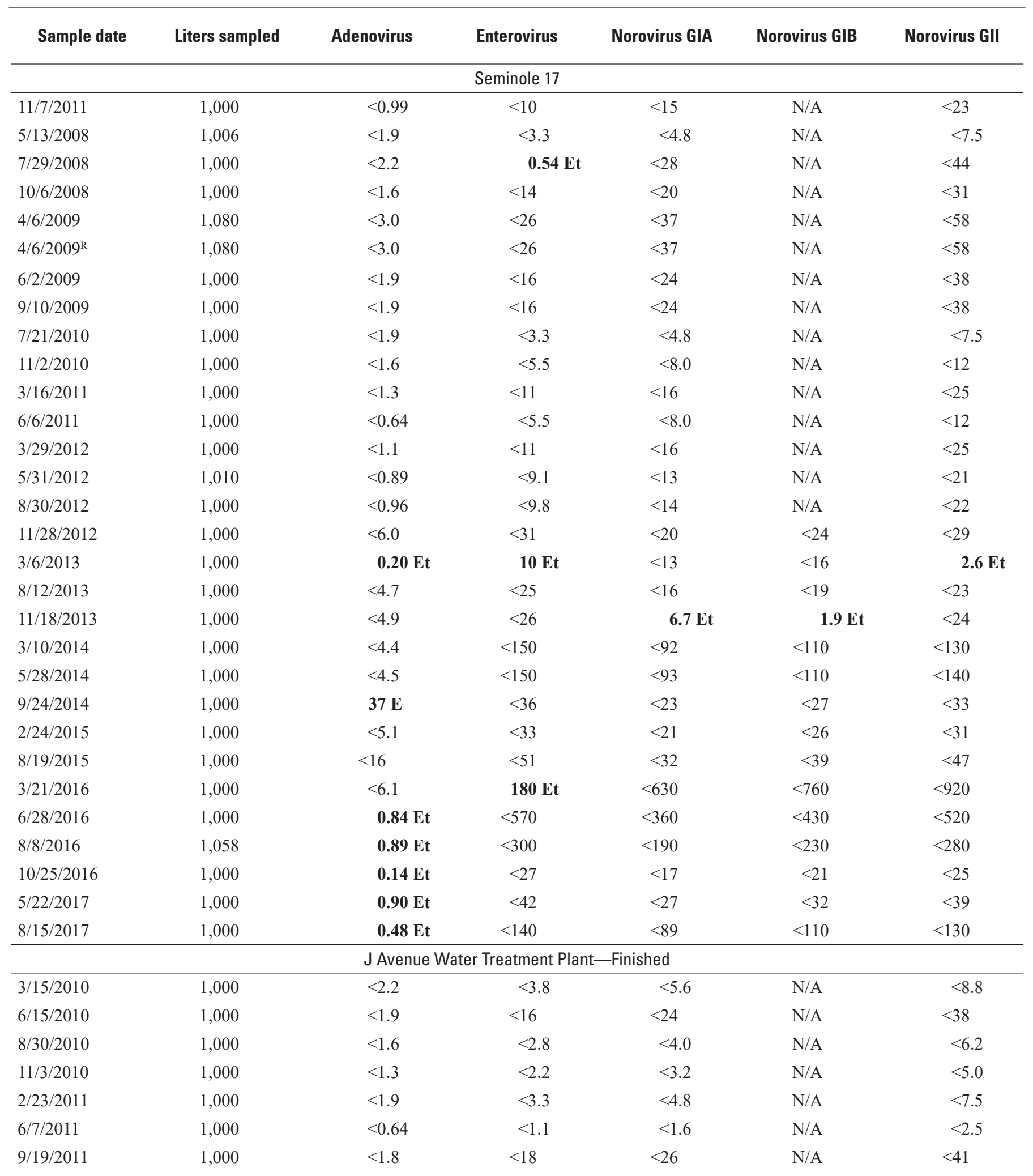


Table 19. Results for quantitative polymerase chain reaction and quantitative reverse-transcription polymerase chain reaction viral pathogen samples, Cedar Rapids, lowa, 2008-17.-Continued

[E, result is estimated; $t$, result is greater than the limit of blank but less than the limit of detection; <, result is below the limit of detection; N/A, not applicable; b, result is extrapolated below the limit of quantification; Ranney, horizontal collector well; CRM, Cedar Rapids Municipal local project identifier; bold values are detections; molecular methods reported in copies per liter]

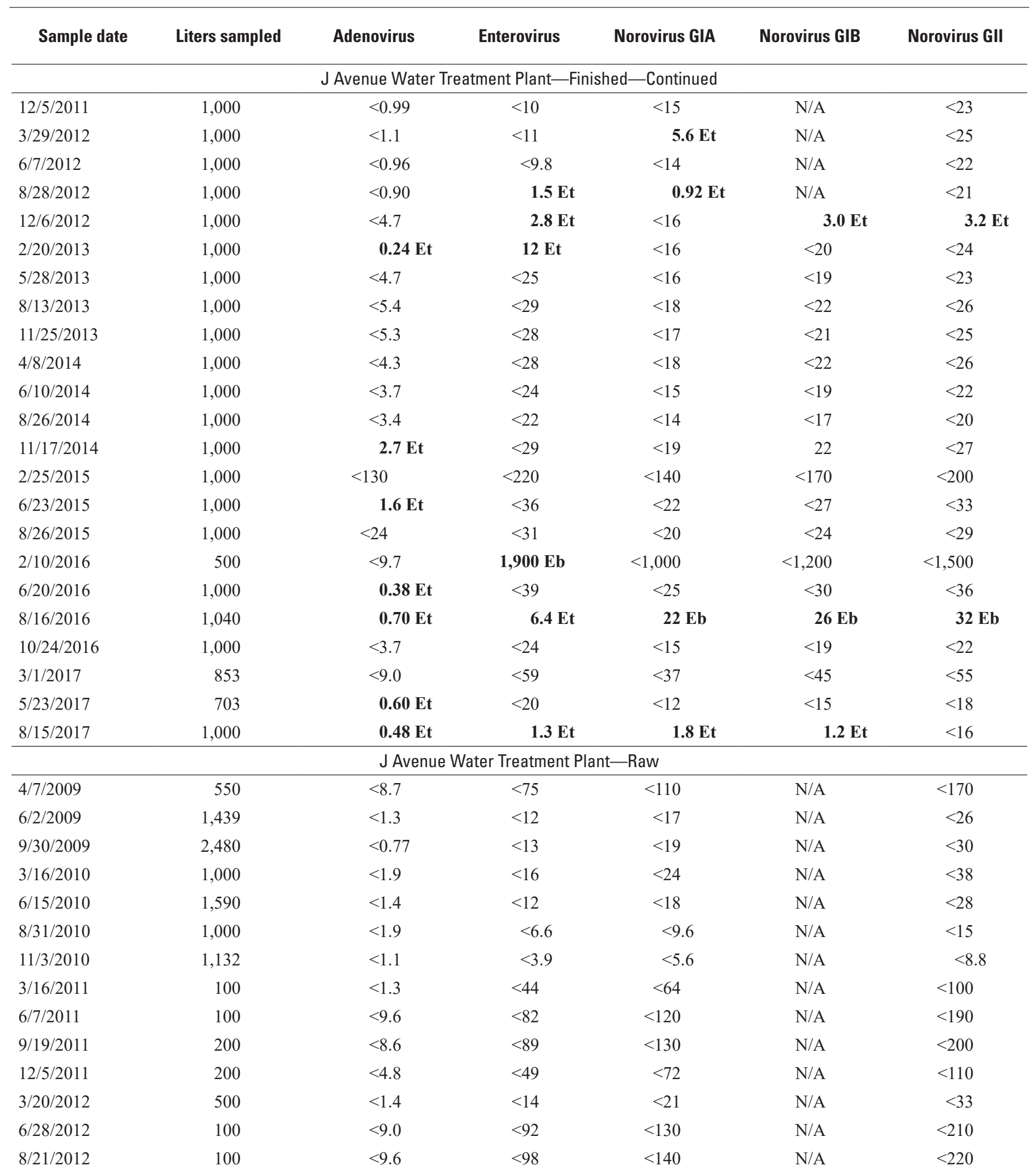


Table 19. Results for quantitative polymerase chain reaction and quantitative reverse-transcription polymerase chain reaction viral pathogen samples, Cedar Rapids, lowa, 2008-17.-Continued

[E, result is estimated; $t$, result is greater than the limit of blank but less than the limit of detection; <, result is below the limit of detection; N/A, not applicable; $\mathrm{b}$, result is extrapolated below the limit of quantification; Ranney, horizontal collector well; CRM, Cedar Rapids Municipal local project identifier; bold values are detections; molecular methods reported in copies per liter]

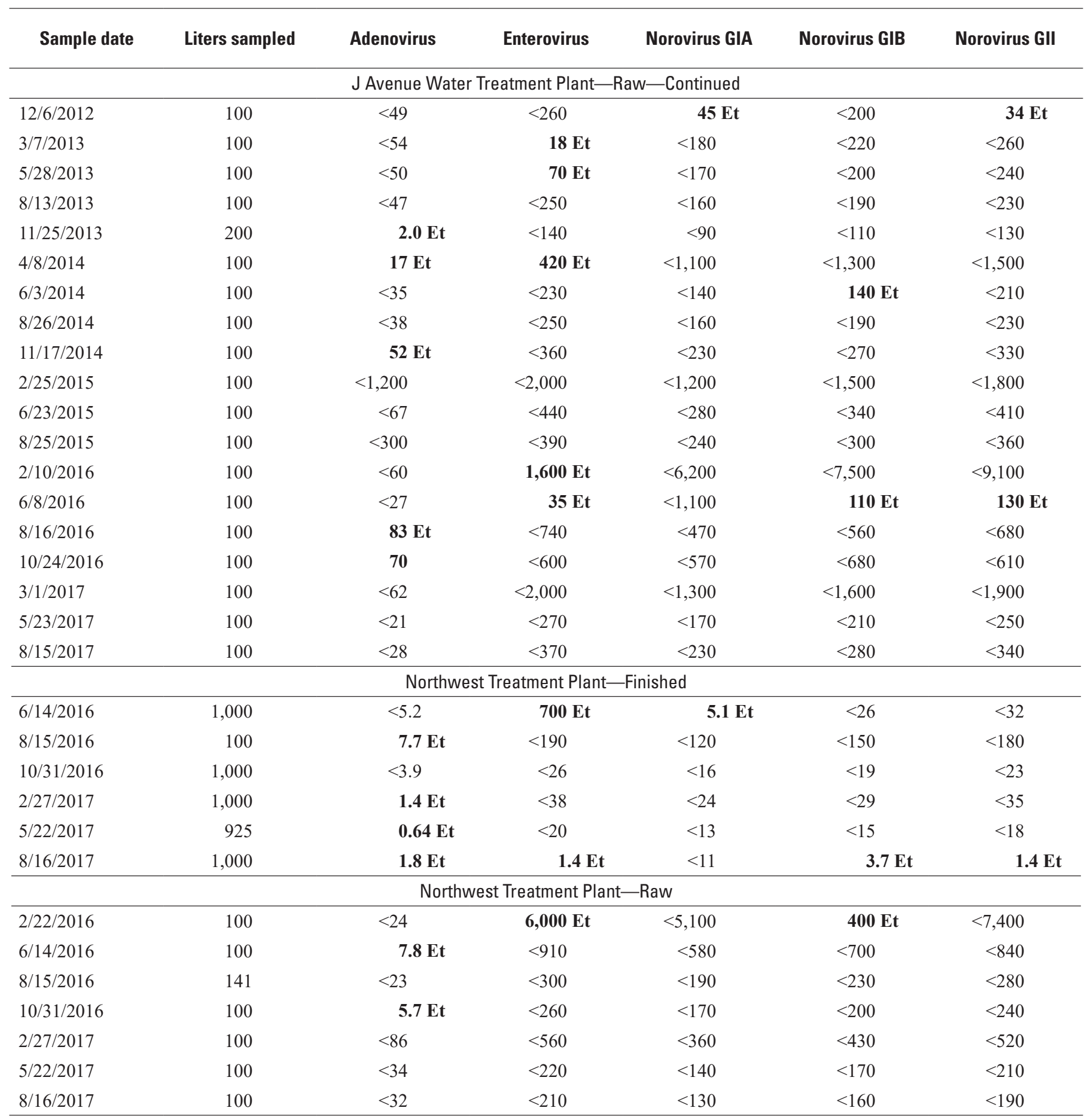

\footnotetext{
${ }^{\mathrm{R}}$ Replicate samples.
} 
For more information about this publication, contact:

Director, USGS Central Midwest Water Science Center

400 South Clinton Street, Suite 269

lowa City, IA 52240

319-337-4191

For additional information, visit: https://www.usgs.gov/centers/cmwater

Publishing support provided by the

Rolla Publishing Service Center 


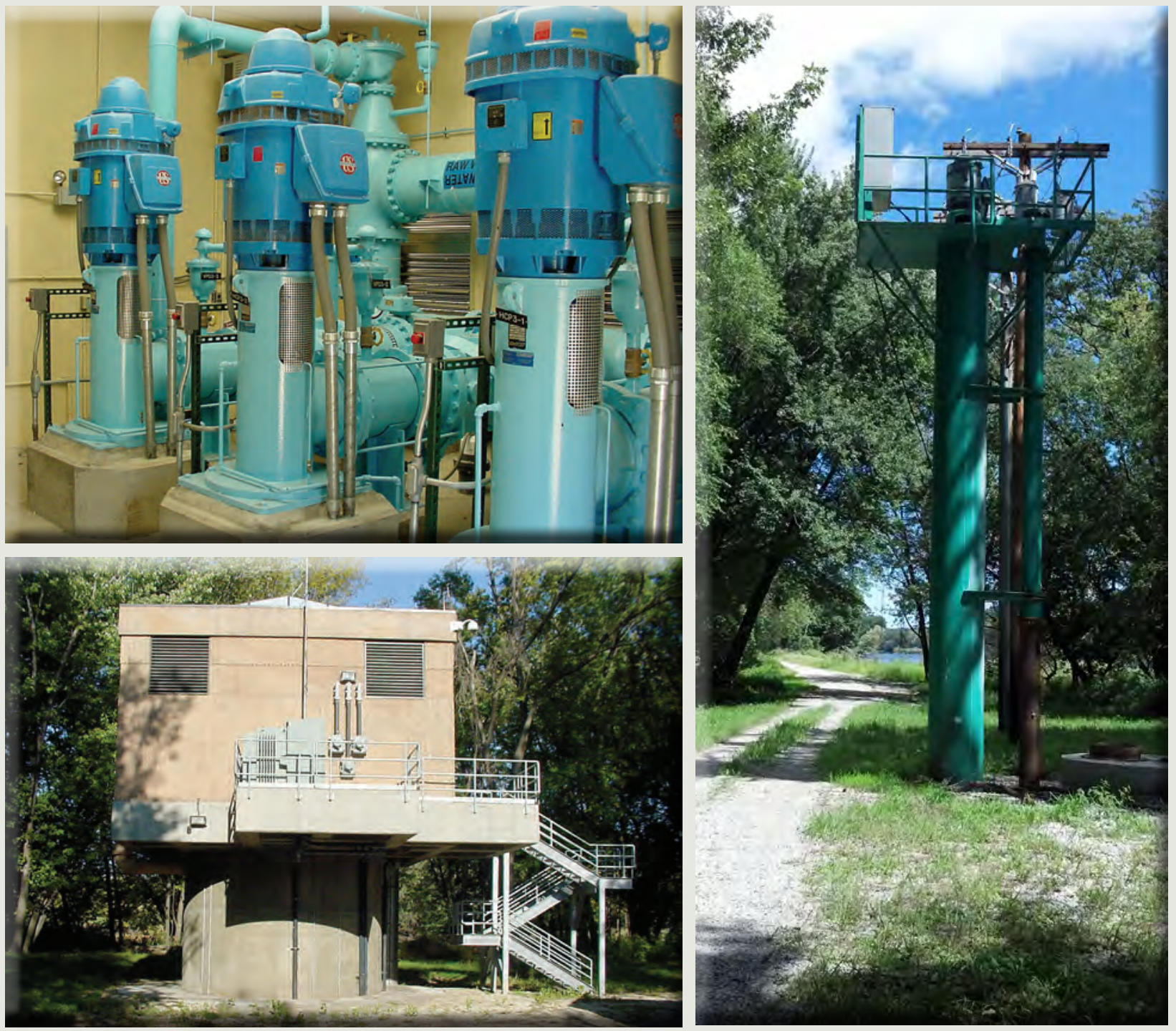

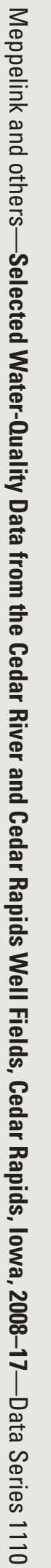

